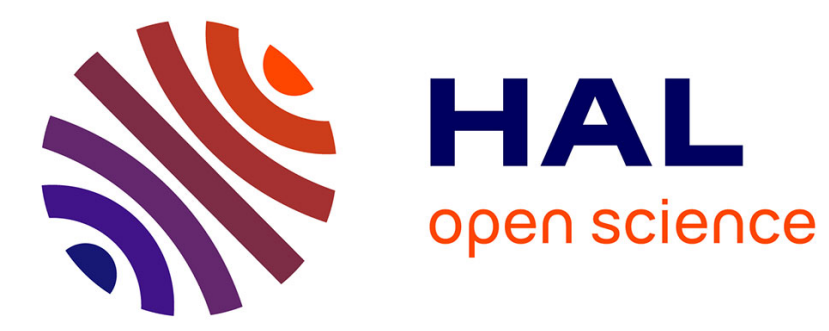

\title{
Thiol isomerases negatively regulate the cellular shedding activity of ADAM17.
}

Sofie H Willems, Christopher James Tape, Peter L. D. Stanley, Neil A Taylor, Ian G Mills, David E Neal, John Mccafferty, Gillian Murphy

\section{- To cite this version:}

Sofie H Willems, Christopher James Tape, Peter L. D. Stanley, Neil A Taylor, Ian G Mills, et al.. Thiol isomerases negatively regulate the cellular shedding activity of ADAM17.. Biochemical Journal, 2010, 428 (3), pp.439-450. 10.1042/BJ20100179 . hal-00486862

\section{HAL Id: hal-00486862 https://hal.science/hal-00486862}

Submitted on 27 May 2010

HAL is a multi-disciplinary open access archive for the deposit and dissemination of scientific research documents, whether they are published or not. The documents may come from teaching and research institutions in France or abroad, or from public or private research centers.
L'archive ouverte pluridisciplinaire HAL, est destinée au dépôt et à la diffusion de documents scientifiques de niveau recherche, publiés ou non, émanant des établissements d'enseignement et de recherche français ou étrangers, des laboratoires publics ou privés. 


\section{THIOL ISOMERASES NEGATIVELY REGULATE THE CELLULAR SHEDDING ACTIVITY OF ADAM17}

Sofie H. Willems, Christopher J. Tape, Peter L. Stanley, Neil A. Taylor, Ian G. Mills $\ddagger$, David E. Neal, John McCafferty+ and Gillian Murphy

Department of Oncology, Cambridge University, Cancer Research UK Cambridge Institute, Li Ka Shing Centre, Cambridge CB2 ORE, UK and +Dept of Biochemistry, Tennis Court Road, Cambridge CB2 1QW, U.K.

Corresponding Author: Gillian Murphy, email gm290@cam.ac.uk. Tel: +441223404470 Fax +441223404573

Running title: Thiol isomerase regulation of ADAM17

KEY WORDS: METALLOPROTEASE, REDOX, PDI, SHEDDING, PROTEIN CONFORMATION, DISULPHIDE

$\ddagger$ current address: Norwegian Centre for Molecular Medicine, Nordic EMBL

Partnership, University of Oslo, Blindern N-0317 Oslo, Norway 
The disintegrin metalloprotease ADAM17 can rapidly modulate cell surface signalling events by the proteolytic release of soluble forms of pro-ligands for cellular receptors. Many regulatory pathways effect ADAM17 sheddase activity, but the mechanisms for its activation are still not clear. We have utilized a cell based ADAM17 assay to show that thiol isomerases, specifically protein disulphide isomerase, could be responsible for maintaining ADAM17 in an inactive form. Down regulation of thiol isomerases, by changes in the redox environment, for instance as elicited by phorbol ester modulation of mitochondrial reactive oxygen species, markedly enhanced ADAM17 activation. Based on ELISA binding studies with novel fragment antibodies to ADAM17 we propose that isomerisation of the disulphide bonds in ADAM17 and the subsequent conformational changes form the basis for the modulation of ADAM17 activity. The shuffling of disulphide bond patterns in ADAMs has been suggested by a number of recent adamalysin crystal structures, with distinct disulphide bond patterns altering the relative orientations of the domains. Such a mechanism is rapid and reversible and the role of thiol isomerases should be investigated further as a potential factor in the redox regulation of ADAM17. 


\section{INTRODUCTION}

The disintegrin metalloproteases of the ADAM family are associated with the process of proteolytic 'shedding' of membrane associated proteins and hence the rapid modulation of key cell signalling pathways in the tumour microenvironment. ADAM17, the TNFa converting enzyme (TACE) represents the archetypal signalling switch, with a plethora of apparent cell membrane substrates, constituting part of the link between the cell and its environment. ADAM17 is thought to effect the proteolytic shedding not only of TNFa, but a number of the EGF receptor ligands, cell adhesion molecules, such as Lselectin, and many growth factor receptors [1, 2]. One of the most important and remarkable features of ADAM17 function is the speed with which it can be activated at the cell surface, allowing the cell to rapidly modulate its signalling status [1]. A major outstanding question is the mechanisms by which this may be effected. ADAM17 activity has been shown to be regulated by phorbol esters [2, 3], kinases and phosphatases, as well as $G$ protein coupled receptor signalling (reviewed in [4]). Reactive oxygen species (ROS) have frequently been identified as mediators of ADAM17 activation in these signalling pathways $[5,6]$ and may be involved in ADAM17 responses to many stress related stimuli [7]. The function of accessory proteins including ARTS-1 [8], nardilysin [9] and CD9 [10] has also been invoked in the modulation of specific ADAM17 shedding activities, although none of the mechanisms of action are clear. The localisation of both enzyme and substrate relative to lipid raft structures in cell membranes has been proposed as a level of regulation [11]. The availability of ADAM17 substrates are likely to be another component of the regulatory mechanism and it is documented that ROS stimulate the trafficking of proHB-EGF to a detergent-resistant membrane compartment, proteolytic processing and release of the soluble mature form [12].

Many of the substrates of ADAM17 are complex disulphide bonded proteins and there have been studies showing that the thiol status of these proteins can modulate their propensity for proteolytic shedding. L-selectin is an example where thiol oxidising or thiol blocking reagents are stimulatory and thiol reducing agents are inhibitory to shedding by ADAM17 [13]. The involvement of cell surface localised protein disulphide isomerase (PDI) as a modulator of the cleavable form of L-selectin was proposed, based on the ability of the PDI inhibitor Bacitracin and an inhibitory antibody to PDI to markedly potentiate shedding [14]. Studies have shown that the thiol reactive reagent, 4-aminophenylmercuric acetate (APMA) can stimulate proteolytic shedding from cells, and effects on both the substrate and the protease have been proposed $[14,15]$. Redox mechanisms for the regulation of extracellular events are of some importance and the presence of redox active proteins has been described for different cell types [16-18]. PDI, which has two active sites containing vicinal thiols that are in equilibrium with disulphide bonds, can catalyse thiol-disulphide interchanges, leading to the net formation or the net reduction of disulphide bonds, or simply their rearrangement. Although largely an endoplasmic reticulum-based protein, an active form of PDI appears at the cell surface and appears to be a dithiol form that catalyses the reduction or isomerisation of disulphide bonded proteins. PDI was shown to expose a 
cryptic cell binding site in TSP-1 [19]. Another thiol isomerase, ERp5 has been shown to regulate adhesion of platelets, probably through the activation of integrins [20]. The exchange of thiols on CD4 by the thiol isomerase, thioredoxin is required for the entry of HIV type 1 into cells [21]. Thioredoxin and PDI are regenerated from their oxidised forms by the enzyme thioredoxin reductase which can also be secreted from cells [22]. All of these proteins have copies of the thioredoxin motif $\mathrm{CxxC}$ which can in principle act as thiol oxidants, reductants or as disulphide isomerases for vicinal dithiols in substrate proteins. Interestingly, ADAM17, like some integrins [23], has two thioredoxin motifs in the disintegrin and cysteine rich domains, respectively. The Walcheck laboratory [24] demonstrated that these motifs are critical for Lselectin cleavage activity of ADAM17, and suggested that ADAM17 might be regulated by extracellular redox conditions, either via PDI or other endogenous thiol isomerase activities. In this study we have shown that PDI has the potential to regulate cellular ADAM17 activity by isomerisation of its disulphide bonds. By the use of novel conformation specific antibodies developed in our laboratory, we show that treatment of recombinant ADAM17 with PDI incurs a change in the accessibility of antibody binding motifs on ADAM17, i.e. a structural change in the protease and a loss of proteolytic activity.

\section{EXPERIMENTAL}

MATERIALS

Unless stated otherwise, chemicals were purchased from Sigma-Aldrich, including purified bovine PDI (P3818). Antibodies were purchased from R\&D (HB-EGF goat anti human \#AF-259-NA), Calbiochem (ADAM10 \#PC528 rabbit anti human), Abcam (ADAM17 \#39162 and \#28233 rabbit anti human, PDI RL90 and RL77 mouse anti rat, thioredoxin \#26320 rabbit anti human, actin 8227 rabbit anti human, alkaline phosphatase \#75699 rabbit anti human). For immunoprecipitations an anti-ADAM17 chicken IgY polyclonal antibody raised to recombinant ADAM 17 was used. (N.Taylor, unpublished). siRNA oligonucleotides to ADAM10, ADAM17 and PDI were purchased from Dharmacon. Protease inhibitor mix Cocktail 1 was purchased from Roche. NTIMP-3 with a C-terminal His tag was prepared as described previously [25]. MitoQ was a kind gift of Dr. M. Murphy (MRC Mitochondrial Biology Unit, Cambridge) [26]. Glutathione S-transferase proTNFa (GST-proTNFa), was prepared as described previously [27]. Protein models are visualised in PyMOL.

\section{METHODS}

Production and assay of recombinant ADAM17

Recombinant ADAM17 ectodomain (TACE651) was expressed from baculovirus (a kind gift of Dr D. Becherer, GlaxoSmithKline) and purified according to the method of Milla et al. [28], with minor modifications. The $60 \mathrm{kDa}$ protein produced represents the mature ectodomain since proprotein convertase processing of the propeptide occurs during sf9 cell expression. The mature catalytic domain of ADAM17 (TACE477GHHis ${ }_{6}$ ) was also 
prepared using the baculovirus system and was the generous gift of $\mathrm{Dr} M$. Taylor and Dr P. Newham, AstraZeneca. In vitro assays of recombinant ADAM17 activity were carried using the quenched fluorescent peptide (7methoxycoumarin-4-yl)acetylLysProLeuGlyProLeuN-3-(2,4-dinitrophenyl)-I2,3-diaminopropionylAlaArgNH ${ }_{2}$ (Calbiochem), as described below.

\section{Cell culture}

HeLa cells (Cancer Research UK; passage 5 to 30 ) were cultured at $37^{\circ} \mathrm{C}$ in DMEM (Dulbecco's Modified Eagle Medium, Gibco) with 10\% foetal bovine serum and $2 \mathrm{mM}$ l-glutamine and used after $24-48 \mathrm{~h}$ at $80 \%$ confluence.

$H B-E G F$ and TNFo alkaline phosphatase shedding assays

A cDNA for proHB-EGF fused to an alkaline phosphatase (AP) reporter (a kind gift of Dr Shigeki Higashiyama [29]), HB-EGF-AP, was cloned into the $\mathrm{pRc} / \mathrm{CMV}$ plasmid (Invitrogen, Carlsbad, CA), which confers neomycin resistance, and was stably transfected into HeLa cells using Fugene 6 (Roche). Stably transfected cells were selected with $800 \mathrm{ng} / \mathrm{ml} \mathrm{G418.} \mathrm{Cellular}$ expression of the fusion proteins was verified by Western blot using an antiHB-EGF and an anti-AP antibody. Unless stated otherwise $2 . \times 10^{4}$ cells were seeded per well of a 48-well plate for each experiment. After $48 \mathrm{~h}$, cells were washed twice with serum free medium and treated with the various agents in serum-free medium at the concentrations and for the time periods indicated. After treatment, medium was collected, spun down at $2.5 \times 10^{3} \mathrm{~g}$ for $5 \mathrm{~min}$ before $40 \mu \mathrm{l}$ medium was removed from each sample and added to $100 \mu \mathrm{l}$ of AP substrate $(5 \mathrm{mM}$ p-nitrophenyl phosphate disodium, $1 \mathrm{mM}$ diethanolamine, $\mathrm{pH}$ 9.5), and $50 \mu \mathrm{M} \mathrm{MgCl}_{2}, 0.15 \mathrm{M} \mathrm{NaCl}, 0.5 \mathrm{M}$ Tris-OH and $5 \mathrm{mM}$ EDTA, pH 9.7). After overnight incubation, AP activity was measured with a Tecan spectrafluor plus microplate reader at $405 \mathrm{~nm}$.

\section{Studies with PDI}

Bacitracin, a general thiol isomerase inhibitor, and the PDI inhibitory antibody, RL90 were used to inhibit PDI. Bacitracin was purified to remove the bulk of contaminating proteases and finally treated with phenylmethanesulphonyl fluoride [30]. Loss of protease activity was confirmed using a myelin basic protein cleavage assay. The PDI inhibitory activity was confirmed in vitro using purified bovine PDI in the insulin reduction assay [31].

Cells were pre-incubated at $4^{\circ} \mathrm{C}$ with Bacitracin $(3 \mathrm{mM})$ for $5 \mathrm{~min}$, or PDI (100 $\mu \mathrm{M})$ for 30 min, followed by stimulation with phorbol myristate acetate (PMA, $100 \mathrm{ng} / \mathrm{ml}$ ) for different durations. The medium was collected, spun down and assayed for AP. Exogenous PDI was added to cells in various concentrations. After 30 min cells were stimulated with PMA $(100 \mathrm{ng} / \mathrm{ml})$ for $30 \mathrm{~min}$. The medium was collected, spun down and assayed for AP.

\section{Studies with ROS inhibitors}

$\mathrm{N}$-acetylcysteine (NAC), which increases intracellular pools of free radical scavengers, and MitoQ, a mitochondrial ROS inhibitor, were used to investigate the effect of (mitochondrial) ROS on ADAM17 activity. Cells were pre-incubated with various concentrations of NAC or MitoQ for $15 \mathrm{~min}$, followed by stimulation with PMA $(100 \mathrm{ng} / \mathrm{ml})$ for $30 \mathrm{~min}$ at $37^{\circ} \mathrm{C}$. The medium was collected, spun down and assayed for AP. 


\section{SDS-PAGE and Western blotting}

Cells were lysed in ice-cold buffer $(50 \mathrm{mM}$ Tris- $\mathrm{HCl} \mathrm{pH} \mathrm{7.4,} \%$ (v/v) Triton X$100,500 \mathrm{mM} \mathrm{NaCl}$ ) with proteinase inhibitor mix for $15 \mathrm{~min}$ at $4^{\circ} \mathrm{C}$. Protein concentration was determined with the BCA protein quantification kit (Pierce). Protein samples mixed with Laemmli sample buffer were separated by SDSpolyacrylamide gels ranging from 6 to $12 \%$. Protein was transferred to Hybond-C nitrocellulose membranes and blocked with PBS or TBS with $5 \%$ low fat milk powder for $2 \mathrm{~h}$ at room temperature (RT) before overnight incubation with the appropriate primary antibody at $4^{\circ} \mathrm{C}$. Blots were washed in PBS or PBS $+/$ - Tween $(0.1 \% \mathrm{v} / \mathrm{v})$ and incubated with horseradish peroxidase conjugated secondary antibody (1/5000) for $1 \mathrm{~h}$ at RT, washed again, developed with enhanced chemiluminescence and exposed to Hyperfilm (GE Healthcare). Films were quantified by densitometry.

\section{Biotinylation experiments}

$5 \times 10^{5}$ subconfluent HeLa cells were used per condition. After cells were incubated with described reagents and for time points indicated, cells were washed and surface biotinylated with EZ-Link Sulfo-NHS-Biotin (labels amine groups, Thermo Scientific) in PBS or with 3-(N-maleimido-propionyl) biocytin (MPB) $(100 \mu \mathrm{M}$, labels thiol groups, Pierce) in HEPES-buffered saline $(0.137$ $\mathrm{M} \mathrm{NaCl}, 5 \mathrm{mM} \mathrm{KCl}$. $0.76 \mathrm{mM} \mathrm{Na} \mathrm{HPO}_{4} \mathrm{H}_{2}, 5.56 \mathrm{mM}$ dextrose, $21 \mathrm{mM}$ Hepes) for $45 \mathrm{~min}$ at $4^{\circ} \mathrm{C}$. EZ-Link Sulfo-NHS-Biotin labelling was quenched with $50 \mathrm{mM}$ Tris-HCL $(\mathrm{pH} 7.5)$ for $10 \mathrm{~min}$ at $4^{\circ} \mathrm{C}$. MPB labelling was quenched with reduced GSH $(200 \mu \mathrm{M})$ in HBS buffer for 20 min at $4^{\circ} \mathrm{C}$. Excess $\mathrm{GSH}$ was quenched with iodoacetamide $(400 \mu \mathrm{M})$ for $5 \mathrm{~min}$ at $4^{\circ} \mathrm{C}$. Subsequently, cells were washed and lysed with lysis buffer (Triton X-100 $(1 \%, v / v), 50 \mathrm{mM}$ Tris- $\mathrm{HCl} \mathrm{pH} \mathrm{7.4,} 150 \mathrm{mM} \mathrm{NaCl}$, protease inhibitors). Lysates were pre-cleared with protein $\mathrm{G}$ Sepharose beads for $30 \mathrm{~min}$ and incubated with streptavidin magnetic beads (Magnasphere, Promega) o/n at $4^{\circ} \mathrm{C}$. To release complex from beads, beads were washed and boiled in SDS $(1 \%, w / v)$ in Laemmli buffer for $2 \mathrm{~min}$. Samples were subjected to SDS-PAGE and Western blot (Biorad Systems) before being probed with specific antibodies against ADAM17 (39162), PDI (RL77) and HB-EGF.

Co-immunoprecipitation studies

$1 \times 10^{6}$ subconfluent HeLa cells were used per condition. After exposure to PMA (100 ng/mi) for 30 min, cells were washed and surface aminobiotinylated with EZ-Link Sulfo-NHS-Biotin as described in the previous section. To trap mixed disulphide intermediate complexes between PDI and ADAM17, cells were incubated in $10 \%(\mathrm{w} / \mathrm{v})$ trichloracetic acid for $30 \mathrm{~min}$ at $4^{\circ} \mathrm{C}$, before the $\mathrm{pH}$ was adjusted to 7.0 with Tris-OH ( $\mathrm{pH}$ 9.5) [32]. Subsequently, cells were washed and lysed with Triton X-100 lysis buffer (1\% Triton X-100 (v/v), 50 mM Tris- $\mathrm{HCl} \mathrm{pH} \mathrm{7.4,} 150 \mathrm{mM} \mathrm{NaCl}$ ) containing protease inhibitors and $\mathrm{N}$ ethylmaleimide. Lysates were passed through a 26G needle before being precleared with protein $G$ Sepharose beads and immunoprecipitation was performed with polyclonal IgY chicken ADAM17 antibody. To release complexes from the beads, samples were washed, boiled in PBS with SDS $(1 \%)$ and then diluted tenfold with buffer $(50 \mathrm{mM}$ Tris- $\mathrm{HCl} \mathrm{pH} 7.4,150 \mathrm{mM}$ $\mathrm{NaCl}$, protease inhibitor mix). Secondary immunoprecipitation was performed 
with streptavidin magnetic beads. Samples were then subjected to SDSPAGE and Western blot. Finally, membranes were probed with specific antibodies against ADAM17, PDI, and $\beta$-actin.

\section{SiRNA studies}

For knockdown of each target gene, 4 different siRNA oligonucleotides were tested by Western blot, two of which were used for the actual experiments. For the experiments with MCF7 cells, a pool of the 4 siRNA oligo's was used (J-003453 5-8). ADAM10 (D-004503 1 and 3) and ADAM17 (J-003453 7 and 8) siRNA crossreactivity was tested as well. Nontargeting siRNA (D-001819) with minimal targeting of known genes was used as a control. ADAM10, ADAM17, PDI (\#J-01982) and nontargeting siRNA were added to cell monolayers and removed after $6 \mathrm{~h}$. After $72 \mathrm{~h}$ cells were stimulated with PMA (100 ng/ml) for $30 \mathrm{~min}$ at $37^{\circ} \mathrm{C}$. The medium was collected, spun down and assayed for AP.

\section{Production of human anti-ADAM17 scFv antibodies}

Recombinant human ADAM17 ectodomain (TACE651) was biotinylated at an approximately $1: 1$ molar ratio using $\mathrm{N}$-succinimidyl biotin (Invitrogen AL-01), checked for wild-type activity in a quenched fluorescent peptide cleavage assay and exposed to the scFv phage-display library of McCafferty [33]. Following two rounds of solution-phase selection, the eluted polyclonal scFv population was cloned into pSANG10-3F [34] and transformed into the E. coli BL21(DE3) (Stratagene 230280). 384 individual scFv clones were isolated from E.coli periplasm and ELISA screened against immobilised recombinant ADAM17 (see below). Comprehensive screening details have been outlined previously [33]. ScFvs A7, A9, D3 and the negative control antibody B9, were further expressed in $500 \mathrm{~mL}$ auto-induction shake flask cultures [34, 35] and purified by FPLC nickel-mediated immobilized metal affinity chromatography.

\section{ELISA characterisation of human anti-ADAM17 scFv antibodies}

For all standard ELISAs, $50 \mu \mathrm{L} /$ well of $100 \mathrm{nM}$ antigen (diluted in $50 \mathrm{mM}$ Tris$\mathrm{HCl}, 10 \mathrm{mM} \mathrm{CaCl}_{2}, \mathrm{pH} 7.4$ ) was coated on a 96-well Maxisorp plate (Nunc 430341) and incubated overnight at $4^{\circ} \mathrm{C}$. The following day, excess antigen was removed by $\times 3200 \mu$ L PBS washes and each well was blocked with 200 $\mu \mathrm{L} 5 \%$ milk/PBS for $1 \mathrm{~h}$ at RT. $50 \mu \mathrm{L}$ of each antibody (diluted in $3 \%$ milk/PBS) was added to each well and incubated for $1 \mathrm{~h}$ at RT. An antiADAM17 polyclonal $\operatorname{lgY}$ and an anti-ADAM10 rabbit polyclonal (Abcam ab10956) (diluted 1:2000 in 3\% milk/PBS) were used as a positive controls when necessary. Unbound primary antibody was removed by x3 $200 \mu \mathrm{L}$ PBSTween $(0.1 \%, v / v)$ washes, followed by $\times 3200 \mu \mathrm{L}$ PBS washes. ScFv binding was detected using $50 \mu \mathrm{L} /$ well anti-FLAG-HRP (Sigma A8592), N-TIMP-3His by anti-His-HRP (R\&D Systems MAB050H) and IgY by goat-anti-chicken-HRP (Abcam Ab6877) (all diluted 1:1000 in PBS with 3\% milk). Following a further incubation/wash cycle, 3,3',5,5'-tetramethylbenzidine (KPL 52-00-01) was added to each well and a chromogenic signal was allowed to develop. The reaction was stopped with $50 \mu \mathrm{L} 1 \mathrm{M} \mathrm{H}_{2} \mathrm{SO}_{4}$ and absorbance was measured at $450 \mathrm{~nm}$ using a Tecan Infinite-200. To determine basic affinity data, scFv titration ELISAs were performed against $100 \mathrm{nM}$ immobilised ADAM17 ectodomain. Kd values were determined from non-linear regression curve 
fitting (one site - specific binding) in GraphPad Prism. To establish epitope proximity, $100 \mathrm{nM}$ of each scFv was ELISA screened against $100 \mathrm{nM}$ recombinant ADAM17 ectodomain (Arg215-Arg651), 100 nM ADAM17 catalytic domain (Arg215-Val477) and 100 nM ADAM10 ectodomain (Thr214Glu672) (R\&D Systems 936-AD-020). The disulphide dependence of each scFv epitope was determined by comparing ELISA binding of each scFv to $100 \mathrm{nM}$ reduced ADAM17 ectodomain (pre-treated with $100 \mu \mathrm{M}$ DTT prior to coating). The ScFv B9 was randomly selected from the naïve v-gene library and used as a negative control in all scFv ELISAs.

\section{PDI-Treated ADAM17 ELISA}

Purified PDI $(30 \mu \mathrm{M})$ was incubated in the presence of 10 -fold molar excess DTT $(300 \mu \mathrm{M})$ for $15 \mathrm{~min}$ at room temperature. Excess DTT was removed by passing the reduced PDI through two desalting columns (Pierce 89882). Reduced PDI was subsequently split into two populations: one stored on ice for $30 \mathrm{~min}$ (reduced PDI) and another incubated with iodoacetamide $(300 \mu \mathrm{M})$ at room temperature for $30 \mathrm{~min}$ (alkylated PDI). $30 \mu \mathrm{M}$ reduced and alkylated PDI preparations were independently added to $10 \mu \mathrm{M}$ biotinylated recombinant human ADAM17 and incubated at $37^{\circ} \mathrm{C}$ for $2 \mathrm{~h}$. In addition, 10 $\mu \mathrm{M}$ ADAM17 was also incubated with $100 \mu \mathrm{M}$ DTT or in buffer alone to provide reduced and non-reduced ADAM17 controls respectively. All reactions were performed in the presence of $50 \mathrm{mM}$ Tris- $\mathrm{HCl}$ and $10 \mathrm{mM} \mathrm{CaCl}_{2}(\mathrm{pH} \mathrm{7.0)}$. Each ADAM17 solution was then diluted to $50 \mathrm{nM}$ and aliquoted $(50 \mu \mathrm{L}$ per well) onto an ELISA plate pre-coated with $50 \mu \mathrm{L} 200 \mathrm{nM}$ streptavidin (Sigma S4762). After a 20 min incubation, each well was washed 6 times with $200 \mu \mathrm{L}$ PBS-Tween $(0.1 \%, v / v)$ to remove non-biotinylated PDI. Immobilised biotinylated ADAM17 was subsequently probed with $50 \mu \mathrm{L}$ scFvs $(100 \mathrm{nM}), \mathrm{N}$ TIMP-3His (200 nM), ADAM17 polyclonal IgY (10 nM) and anti PDI (RL$77,100 \mathrm{nM}$ ), all diluted in PBS with $3 \%$ milk. Following a $1 \mathrm{~h}$ incubation at room temperature, each well was washed 3 times with $200 \mu \mathrm{L}$ PBS-Tween $(0.1 \% \mathrm{v} / \mathrm{v})$ and 3 times with $200 \mu \mathrm{L}$ PBS. Subsequent immunoreactivity was detected as detailed above.

Fluorimetric ADAM17 activity assay

$0.8 \mathrm{mM}$ ADAM17 651 was incubated in $50 \mathrm{mM}$ Tris- $\mathrm{HCl}, 10 \mathrm{mM} \mathrm{CaCl}$, $\mathrm{pH} 7.4$ either with or without three-fold molar excess of untreated bovine PDI at RT for the times stated. Aliquots were removed and assayed for ADAM17 activity against the fluorogenic substrate methoxycoumarinyl acetyl - Lys-Pro-LeuGly-Leu-dinitrophenyl diaminopropionyl-Ala-Arg- $\mathrm{NH}_{2}$ (2 $\mathrm{mM}$ in FAB buffer: 50 $\mathrm{mM}$ Tris- $\mathrm{HCl}, 10 \mathrm{mM} \mathrm{CaCl}_{2}, 0.05 \%$ Brij35, 1\% DMSO, pH 7.4). Reactions were run for $1000 \mathrm{sec}$ in an LS50B spectrophotometer with a total volume of 2 $\mathrm{ml}$ with excitation at $320 \mathrm{~nm}$ and emission at $405 \mathrm{~nm}$. Activities are expressed as a percentage of the untreated control.

Protein substrate assay.

$100 \mathrm{nM}$ recombinant ADAM17 was treated with increasing amounts of reduced $\mathrm{PDI}(0-800 \mathrm{nM})$ or with reduced and alkylated $\mathrm{PDI}(800 \mathrm{nM})$ in FAB buffer (50 mM TrisHCl, $10 \mathrm{mM} \mathrm{CaCl}_{2}, 0.05 \%$ Brij35, 1\% DMSO, pH7.4) for $2 \mathrm{~h}$ at $37^{\circ} \mathrm{C}$. Subsequently, $5 \mu \mathrm{M}$ GST-proTNF $\alpha$ was added to samples and 
incubated for $2 \mathrm{~h}$ at $37^{\circ} \mathrm{C}$. Each variable was resolved on a reducing $12 \%$ SDS-PAGE and stained with Coomassie Brilliant Blue.

Statistical analysis

All statistical analyses were performed using Graphpad Prism. Where possible, experiments were performed in biological triplicate and were repeated at least twice. Error bars in all figures refer to standard error of the mean.

\section{RESULTS \\ Redox status modulates PMA stimulation of ADAM17 activity in a cell model of HB-EGF shedding}

Using HeLa cells stably transfected with proHB-EGF fused to an alkaline phosphatase reporter, HB-EGF-AP, we confirmed previous data that it was rapidly 'shed' when the cells were stimulated with PMA (Supplementary data Fig.S1a) [36]. Stimulated shedding activity was abrogated completely by treatment with TIMP-3 or low molecular weight inhibitors of metalloproteinases (Fig.S1b). Transient transfection of siRNAs targeting ADAM17 that ablated its expression by up to $90 \%$ inhibited PMA stimulated shedding activity by up to $70 \%$ (Fig.1a.b), indicating that ADAM17 is the major sheddase. Endogenous shedding of HB-EGF-AP by unstimulated cells was low and was unaffected by ADAM17 siRNA treatment (Fig.1a). Specific ADAM10 siRNAs that reduced ADAM10 protein levels more than $75 \%$ had no effect on PMA induced shedding activity (Fig.1a,b). As recently described by Wang et al [24], the treatment of cells with the reducing agents DTT or TCEP was inhibitory to PMA stimulated cellular ADAM17 shedding of L-selectin and we observed similar effects with HB-EGF-AP as the substrate (Fig.2a,b).

It has been shown that PMA treatment of cells causes the generation of reactive oxygen species (ROS) [37], and that oxidising agents agents such as $\mathrm{H}_{2} \mathrm{O}_{2}$ can cause HB-EGF shedding by cells [38] and can activate ADAM17 [24]. Although exogenous $\mathrm{H}_{2} \mathrm{O}_{2}$ was also mildly stimulatory to HB-EGF-AP shedding in our model (data not shown), we found that the effect of PMA on ADAM17 activity in HeLa cells was not inhibited by the presence of the antioxidant catalase (data not shown). However, the presence of the general free radical scavenger, $\mathrm{N}$-acetylcysteine (NAC) or the mitochondrial electron transport chain inhibitor MitoQ was inhibitory (Fig.2c.d), implicating mitochondrial ROS in the mode of PMA action on ADAM17 in HeLa cells.

\section{Thiol isomerases modulate HB-EGF shedding}

Mature ADAM17 is thought to have 16 disulphide bonds [39]. There is considerable potential for isomerisation, notably of the two CxxC isomeraselike motifs in the disintegrin and cysteine rich domain, which appear to be essential for ADAM17 activity [24, 40]. Therefore we postulated that these might be susceptible to changes in the cellular redox environment. Thiol 
isomerases such as PDI and thioredoxin that are sensitive to redox changes, have been implicated in the regulation of the thiol and disulphide bond status and activity of various cell surface proteins [17]. We therefore investigated their potential role in the modulation of ADAM17 activity. We found that the general thiol isomerase inhibitor Bacitracin was indeed an efficient activator of HB-EGF-AP shedding, almost doubling its release in the presence of PMA, although it had little effect on constitutive shedding (Fig.3a). We confirmed that HB-EGF-AP shedding was still due to ADAM17 using specific siRNA ablation (Fig.3b). We hypothesised that certain disulphide isomers of ADAM17 could be less active than others and that an inactive form might be maintained by cellular thiol isomerase(s) activity. In support of this concept, an inhibitory antibody to PDI was found to enhance PMA shedding by around $60 \%$ (Fig.3a,b). This suggests that PDI could be a specific contributor to the thiol isomerase activities that are responsible for the down-regulation of ADAM17 activity. Equally, addition of exogenous PDI to cells was moderately inhibitory (about $30 \%$ ) to PMA stimulated shedding, with no significant effect on endogenous shedding (Fig.3c), suggesting that endogenous PDI levels are largely sufficient to maintain ADAM17 in a low activity form, or that (reduced) exogenous PDI is rapidly down-regulated by the PMA-induced oxidative environment induced here. When the thiol groups of exogenous PDI are blocked by reduction and alkylation, the inhibitory effect on ADAM17 activity is abrogated (Fig.3d). This indicates that PDI thiol groups are necessary for the regulation of ADAM17 sheddase activity. Reduction of total cellular PDI levels by transfection of siRNAs targeting PDI (approx. 80\% depletion of protein levels; Fig.3f) enhanced the effect of PMA stimulated shedding by about 2 fold (Fig.3e). As for Bacitracin or anti PDI treatment, this mode of PDI inhibition had no significant effect on constitutive cellular shedding of HB-EGF-AP. Another potential thiol isomerase, reduced thioredoxin, was a rather weak inhibitor of PMA stimulated ADAM17 activity, but was not very stable in its reduced form (data not shown).

In summary, ablation of PDI activity (antibody, siRNA) enhanced the action of PMA stimulated pathways in HeLa cells. Comparable data were obtained using MCF7 cells (Supplementary data Fig.S2,S3). We conclude that PMA might act in part via a PDI-mediated thiol isomerase mechanism which involves the modification of PDI redox activity.

\section{ScFv antibodies and TIMP-3 detect PDI modulation of recombinant ADAM17}

Using a recombinant form of the full ectodomain of human ADAM17 we have isolated ScFv antibodies from a V-gene phage display library [33]. Using an ELISA assay with full length ADAM17 ectodomain, or the catalytic domain alone we identified an antibody that exhibited specificity for the catalytic domain of ADAM17 (A9; Kd $30 \mathrm{nM}$ ) and two antibody clones that required the presence of the non-catalytic regions (disintegrin-cysteine rich domain) (A7; $\mathrm{Kd} 90 \mathrm{nM}$ and D3, Kd $20 \mathrm{nM}$ ) (Fig.4a,b). A randomly selected control scFv B9 failed to bind all antigens (Fig.4a) and was used as a negative control in all subsequent ELISAs (data not shown). None of the antibodies bound to recombinant ADAM10 (Fig.4b). The 16 potential disulphide bonds in the ectodomain of ADAM17 are thought to be key elements in the determination 
of its tertiary structure [41]. Since all scFvs were selected against non-reduced ADAM17 (with no detectable free thiols), disulphide dependent antigen topology could result in scFvs harbouring disulphide dependent epitopes. To explore this idea, the binding of each ScFv to reduced ADAM17 was investigated. Treatment of ADAM17 with DTT strongly reduced immunoreactivity with $A 7$ and $A 9$ (Fig.4c), indicating that they do indeed recognise complex 3-dimensional disulphide dependent epitopes. In contrast, DTT treatment had no effect on ADAM17 binding to D3, suggesting a simple linear epitope (Fig.4c). ScFvs A7, A9 and D3 were subsequently used to monitor PDI modulation of recombinant ADAM17 ectodomain. Treatment of ADAM17 with reduced PDI substantially abrogated ADAM17 recognition by A7 and D3 (non-catalytic epitope), but not by A9 (catalytic epitope) (Fig.4d, Table 1). Similar data were obtained with untreated PDI, suggesting the purified enzyme exists in a reduced, active state (data not shown). PDI that had been previously inactivated by reduction and alkylation had no effect on ADAM17 immunoreactivity against D3, A7 or A9 - indicating the reduced thiols of PDI were essential for ADAM17 modulation. All forms of ADAM17 used in the assays were equally well recognised by a polyclonal antibody $\lg Y$ to ADAM17 (Fig.4c). The possibility that non-specific binding of PDI could be responsible for changes in scFv binding were ruled out since an antibody to PDI, RL-77, showed that no PDI remained in the assays after the wash protocol was employed (data not shown). Treatment of ADAM17 with reduced thioredoxin (at a concentration equivalent to equimolar thioredoxin motifs of PDI) caused a small decrease in $A 7$ and $D 3$ immunoreactivity towards ADAM17, but was not as effective as PDI (data not shown). Interestingly, PDI treatment of ADAM17 ectodomain reduced its ability to bind the $\mathrm{N}$-terminal domain of TIMP-3, N-TIMP-3 (Fig.4e). However, PDI treatment of ADAM17 did not disrupt the disulphide dependent catalytic domain epitope of scFv A9, suggesting that the ADAM17 catalytic domain remained unaltered.

In summary, our data indicate that PDI treatment of ADAM17 modifies the epitopes of scFvs $A 7$ and D3, presumably by a structural change in the noncatalytic ADAM17 disintegrin, cysteine-rich domain. Moreover, PDI treatment also modifies accessibility of N-TIMP-3 to the ADAM17 catalytic site whilst retaining the disulphide-dependent catalytic domain epitope of scFv A9. Finally, recombinant ADAM17 cleavage of a quenched-fluorescent peptide substrate (Fig.5a) or of macromolecular substrates, GST-proTNFa (Fig.5b) and myelin basic protein (data not shown), could be inhibited by pre-treatment with PDI, but not with alkylated PDI. Together, these results suggest that PDI acts by isomerising the disulphide bonds in the non-catalytic domains of ADAM17, causing a conformational shift in the enzyme structure and obstruction of access to the ADAM17 catalytic site.

\section{PMA modulates the thiol status of PDI but not ADAM17}

We also investigated whether PMA had any effects on PDI and ADAM17 interactions at the cell surface. Although PDI is largely associated with the endoplasmic reticulum, we were able to detect PDI expression at the HeLa cell surface by immunofluorescence (data not shown). This has previously 
been described for a number of different cells [42]. Biotinylation of cell surface proteins with sulfo-NHS-biotin, a reagent reactive with free amino groups, was used to verify by immunoblotting the presence of both mature ADAM17 and PDI at the surface of HeLa cells before and after brief PMA treatment. The level of total cell surface ADAM17 and of PDI did not change significantly after 30min. exposure to PMA (Fig.6a,b) Total cellular levels of HB-EGF were not modified by PMA exposure, but levels at the cell surface decreased, as might be expected (Supplementary data, Fig.S4). The lack of actin biotinylation during cell surface labelling confirmed that biotinylation of intracellular proteins had not occurred. In studies of ADAM17 trafficking in the pre-monocytic cell line THP-1, a similar biotinylation study by the Black laboratory showed that cell surface ADAM17 levels had started to decrease after 30min. PMA treatment [3]. Levels of ADAM17 are somewhat lower in HeLa cells and turnover at the cell membrane appears to be slower in our study. However, after PMA treatment for $1 \mathrm{~h}$ we also began to observe the disappearance of surface ADAM17 (data not shown). Labelling with a cell impermeable thiol biotinylating reagent 3-(N-maleimidopropionyl)-biocytin (MPB) showed that cell surface ADAM17 has some free thiol reactivity and that this does not change significantly in the presence of PMA (Fig.6a,b). In contrast, the free thiol content of PDI fell by about $40 \%$ relative to unstimulated cells, suggesting that it was more oxidised after PMA exposure and potentially less active. When cells were treated with PMA in the presence of the ROS scavenger NAC the total level of cell surface PDI protein (sulfo-NHS biotin labelled) fell, but the level of free thiols associated with the extracellular PDI (MBP labelled) was restored to that of non PMA stimulated cells (Fig.6c). We conclude that PMA generated ROS have modulated the level of active reduced PDI at the cell surface, with consequent effects on the active isomer of ADAM17.

We were unable to detect PDI functional activity at the surface of HeLa cells due to the poor sensitivity of the available assays. The level of reduced PDI detectable by MBP was therefore used as a surrogate assay for PDI activity as an ADAM17 isomerase. The functional association between ADAM17 and PDI was biochemically analysed. Initial failure to co-immunoprecipitate the proteins from lysates of surface biotinylated HeLa cells showed that ADAM17 and PDI do not form stable complexes. This was confirmed by surface plasmon resonance studies of isolated PDI-ADAM17 binding which showed that only extremely transitory complexes formed (data not shown). However, PDI co-immunoprecipitated with ADAM17 when cells were treated with trichloracetic acid, implying that trapping of transient mixed disulphide intermediate complexes can occur, as described by Kaiser et al [32]. After PMA treatment there was no detectable change in this binding (Fig.6d). By immunoblotting, no evidence for association of the thiol isomerases ERp5 and thioredoxin, or the substrate HB-EGF-AP with ADAM17 could be detected (data not shown).

In contrast to the cellular enzyme, the recombinant ADAM17 ectodomain was found to have no free thiol activity and did not bind the thiol reagent MPB (Fig.S5). Purified PDI had extensive levels of free thiols which were lost after treatment with $\mathrm{H}_{2} \mathrm{O}_{2}$ or the alkylating agent iodoacetamide. Incubation of recombinant ADAM17 with PDI caused no change in the free thiol status of either protein (Fig.S5). We conclude that any effect of PDI on ADAM17 is due 
to its isomerase activity rather than as a reducing agent. PMA modulation of cellular ADAM17 activity is down-regulated by counteracting surface PDI activity. Removal of PDI by an inhibitory antibody or siRNA treatment of cells thus gives a marked enhancement of ADAM17.

\section{DISCUSSION}

The rapid activation of ADAM17 to cause cleavage and 'shedding' of cell associated factors such as TNFa and EGF receptor ligands has long been known to be efficiently effected by the activation of protein kinase $C$ by the phorbol ester PMA, or by inhibition of protein tyrosine phosphatases [1]. Although spatial regulation of ADAM17 and its substrates within the plasma membrane may control shedding events it has proved difficult to unequivocally substantiate this concept. PMA has been shown to ultimately decrease the levels of ADAM17 at the surface of monocytic cells, although lipopolysaccharide stimulation had no effect and no change in localisation could be seen [3]. PMA has also been shown to enhance short term activity of ADAM17 against a peptide substrate [43]. Roles for ROS, generated by plasma membrane NADPH oxidases or by mitochondria, downstream of phorbol ester stimulation of protein kinase $\mathrm{C}$, have been previously proposed as mediators of shedding activities [5-7]. The cellular modulation of substrate availability in response to stimuli such as ROS generation is known to be a significant factor in the determination of rates of release of membrane bound growth factors $[1,12,13]$. ProHB-EGF has been shown to be exported from the nucleus of bladder cancer cells in response to increases in ROS and recruited to a lipid raft fraction where cleavage occurred. These trafficking events were key to the proteolytic release of soluble HB-EGF [12].

ROS have been invoked in many of the cellular stress responses that upregulate ADAM17 shedding activity. Wang et al [24] found that neutrophil ADAM17 could be mildly activated by $\mathrm{H}_{2} \mathrm{O}_{2}$ and proposed that reductionoxidation modifications of cysteine sulphydryl groups in ADAM17 may be regulating its L-selectin shedding activity at the cell surface. Since we had similar data using $\mathrm{H}_{2} \mathrm{O}_{2}$ as a stimulant, we proposed to focus on the potential mechanisms of redox modulation of ADAM17 itself. We could show that exposure of Hela cells to inhibitors of PDI, including the metallo-antibiotic Bacitracin, that inhibits enzyme catalysed disulphide exchange, antibodies to PDI, or siRNAs ablating PDI could indeed upregulate PMA stimulated ADAM17 mediated shedding of HB-EGF-AP. These data led us to propose that PDI, and possibly other thiol isomerases, could modulate ADAM17 function, as has been shown for other disulphide bonded cell surface proteins, such as some integrins [17]. We obtained similar data with other cell types, e.g. MCF7 cells (Supplementary data; Fig.S2,3), suggesting that this could be a general regulatory mechanism. Biotin labelling studies using the thiol reactive agent MBP showed that short term treatment of cells with PMA reduces the free thiol level of extracellular PDI by over $40 \%$, but had no effect on ADAM17. A low level of free thiols was detected on cellular ADAM17 
suggesting that a degree of flux between free thiol groups and disulphide bonds may be occurring, but we could not detect a significant difference before and after PMA treatment of cells. We concluded that PDI could be acting as an isomerase of ADAM17, modulating the disulphide bond patterning, but not the overall ratio of free sulphydryl groups to disulphides, with the effect of maintaining an inactive isomer of ADAM17. This concept was supported by our studies with recombinant ADAM17 ectodomain, in which PDI treatment caused conformation changes, as reported by conformation specific antibodies, without any changes in free thiol status. This also led to a decrease in the ability of ADAM17 to cleave both a small fluorescent peptide substrate and larger protein substrates, as well as to bind to N-TIMP-3 in an ELISA style assay. The N-TIMP-3 data concur with our previous observations that the disintegrin-cysteine rich domain of ADAM17 interferes with binding and inhibition of the catalytic domain $[44,45]$. PDI had no effect on the activity of ADAM17 metalloproteinase domain alone (data not shown). The disulphide bond patterning of ADAM17 could determine its conformation and PDI modulation of that pattern would hence modify the shape and function of the enzyme. Mutation of Cys600 in ADAM17 has been shown to lead to a loss of activity of the mutants expressed in transfected cell and implying its importance for enzyme function [40]. However, endoplasmic reticulum folding problems occur for many Cys mutants of ADAM17 (N.Taylor and G. Murphy, unpublished observations), which means that the data are harder to interpret, since there may never be a secreted form. Studies of the crystallographic structure of related snake venom adamalysins have suggested that there could be at least two radically different ' $C$ ' and ' $\mathrm{l}$ ' conformations of the enzymes that reflect different disulphide bonding patterns of the disintegrin-like domain (Fig.7) [46]. Hence ADAM17 could adopt similarly 'closed' and 'open' conformations in which the disintegrin, cysteine rich domains modify accessibility of substrates to the metalloproteinase active site cleft.

The question of how PMA treatment of cells regulates PDI may be partly explained by the modulation of the redox environment through ROS generation, hence reducing the level of free thiol groups. It is still not clear why the presence of PMA facilitates the effective inhibition of PDI to allow further activation of ADAM17 when PDI inhibition of resting cells has no effect. One possibility is that PDI and ADAM17, or ADAM17 and its substrate HBEGF, are brought into proximity to each other in a specific membrane compartment at, or near, the cell surface. However, we have not been able to demonstrate differences in their cell surface localisation in the presence or absence of PMA. As shown in Fig.6d we found little difference in the amount of extracellular PDI-ADAM17 complex with and without PMA stimulation. It is known that PMA regulates the dynamics of the early endosome compartment of cells [47], hence future studies will focus on the role of the plasma membrane in PMA effects the extracellular function of PDI.

Thiol isomerase activity of PDI is thought to be largely confined to the endoplasmic reticulum during protein folding, although isomerisation of thrombospondin-1 extracellularly has been described [42]. The ability of rapid changes of redox status at the cell surface to modulate the behaviour of proteins has long been appreciated. In the case of integrins the effect of PDI 
on conformation and activity has been monitored in a similar fashion using conformation specific antibodies and interactions with ligands [18]. It is significant that this mode of regulation can be extended to membrane proteases such as ADAM17 and possibly to other members of the ADAM and ADAM-TS families that have numerous disulphide bonds and apparently rapid activation mechanisms, and poses the question of the importance of redox and thiol isomerases in the regulation of the pericellular environment. The role of ROS generation in response to many cellular stimuli, including stress responses, in the modulation of the redox environment both intra- and extracellularly is thought to be instrumental in the regulation of many signalling pathways. Effects on thiol isomerases could be key to such effects, with ADAM17 amongst the targets.

Author contribution:

Gillian Murphy designed and co-ordinated the study. Sofie Willems carried out the cell based experiments and some of the recombinant protein studies. John McCafferty developed the peptide library and advised on use. Christopher Tape made and characterised the ADAM17 scFv antibodies, carried out the antibody studies and some of the other recombinant protein studies. Peter Stanley provided the recombinant ADAM17 and performed the peptide substrate assay. Neil Taylor contributed reagents and initial development of protocols. Ian Mills and David Neal gave technical advice and contributed to the preparation of the paper. Gillian Murphy and Sofie Willems prepared the manuscript.

Acknowledgements:

We thank members of the Murphy and Neal Groups and Drs Philip Hogg and Pierre Dilda for discussions and advice on methods. Thanks to Ms Sarah Dombernowsky for the GST-pro TNFa assay protocol and Mrs Val Curry for provision of N-TIMP-3His. Thanks to Dr David Becherer (GlaxoSmithKline) for the TACE651 expressing baculovirus, to Drs Mark Taylor and Peter Newham (AstraZeneca) for TACE477, to Dr Shigeki Higashiyama for the proHB-EGFAP cDNA and to Dr. Rosalyn Adam for MCF7 cells overexpressing proHB-EGF-AP.

Funding:

This study was supported by Cancer Research UK (SHW, CJT, PLS, NAT, GM, IGM, DEN) and Atlantic Philanthropies (GM, DEN).

Abbreviations used: ADAM, a disintegrin and metalloprotease; AP, alkaline phosphatase; APMA, 4amino phenylmercuric acetate; Cys, cysteine; DMSO, Dimethyl sulphoxide; DTT, Dithiothreitol; EGFR, epidermal growth factor receptor; ELISA, enzyme-linked immunosorbent assay; ERp5, endoplasmic reticulum protein 5; GST, glutathione S-transferase; HBS, HEPES-buffered saline; HBEGF, heparin binding EGF; HRP, horseradish peroxidase; FPLC, Fast protein liquid; chromatography; MPB, 3-(N-maleimido-propionyl) biocytin ; NAC, N-acetylcysteine PDI, protein disulphide isomerase; N-TIMP-3: N-terminal domain of TIMP-3; PMA, phorbol myristate acetate ; TACE, TNFa converting enzyme; ROS, reactive oxygen species; PMSF. phenyl methane sulphonyl fluoride; TNF $\alpha$, tumour necrosis factor $\alpha$; scFv, single-chain variable fragment; siRNA, Small interfering RNA; TCEP, tris(2-carboxyethyl)phosphine; TIMP-3: tissue inhibitor of metalloproteinase3, TSP-1, thrombospondin-1

\section{REFERENCES}


1 Murphy, G. (2009) Regulation of the proteolytic disintegrin metalloproteinases, the 'Sheddases'. Semin Cell Dev Biol. 20, 138-145

2 Schlondorff, J., Becherer, J. D. and Blobel, C. P. (2000) Intracellular maturation and localization of the tumour necrosis factor alpha convertase (TACE). Biochem.J. 347 Pt 1, 131-138

3 Doedens, J. R. and Black, R. A. (2000) Stimulation-induced down-regulation of tumor necrosis factor-alpha converting enzyme. J.Biol.Chem. 275, 14598-14607

4 Edwards, D. R., Handsley, M. M. and Pennington, C. J. (2008) The ADAM metalloproteinases. Mol Aspects Med. 29, 258-289

5 Myers, T. J., Brennaman, L. H., Stevenson, M., Higashiyama, S., Russell, W. E., Lee, D. C. and Sunnarborg, S. W. (2009) Mitochondrial Reactive Oxygen Species Mediate GPCR-induced TACE/ADAM17-dependent Transforming Growth Factor\{alpha\} Shedding. Mol Biol Cell. 20, 5236-5249

6 Zhang, Z., Oliver, P., Lancaster, J. R., Schwarzenberger, P. O., Joshi, M. S., Cork, J. and Kolls, J. K. (2001) Reactive oxygen species mediate tumor necrosis factor alpha-converting, enzyme-dependent ectodomain shedding induced by phorbol myristate acetate. FASEB J. 15, 303-305

7 Fischer, O. M., Hart, S., Gschwind, A., Prenzel, N. and Ullrich, A. (2004) Oxidative and osmotic stress signaling in tumor cells is mediated by ADAM proteases and heparin-binding epidermal growth factor. Mol Cell Biol. 24, 5172-5183

8 Cui, X., Rouhani, F. N., Hawari, F. and Levine, S. J. (2003) An aminopeptidase, ARTS-1, is required for interleukin-6 receptor shedding. J Biol Chem. 278, 28677-28685

9 Nishi, E., Hiraoka, Y., Yoshida, K., Okawă, K. and Kita, T. (2006) Nardilysin enhances ectodomain shedding of heparin-binding epidermal growth factor-like growth factor through activation of tumor necrosis factor-alpha-converting enzyme. $\mathrm{J}$ Biol Chem. 281, 31164-31172

10 Imhof, I., Gasper, W. J. and Derynck, R. (2008) Association of tetraspanin CD9 with transmembrane TGF alpha\} confers alterations in cell-surface presentation of TGF \{alpha\} and cytoskeletal organization. J Cell Sci. 121, 2265-2274

11 Tellier, E., Canault, M., Rebsomen, L., Bonardo, B., Juhan-Vague, I., Nalbone, G. and Peiretti, F. (2006) The shedding activity of ADAM17 is sequestered in lipid rafts. Exp Cell Res. 312, 3969-3980

12 Kim, J., Adam, R. M. and Freeman, M. R. (2005) Trafficking of nuclear heparin-binding epidermal growth factor-like growth factor into an epidermal growth factor receptor-dependent autocrine loop in response to oxidative stress. Cancer Res. $\mathbf{6 5}, 8242-8249$

13 Smalley, D. M. and Ley, K. (2005) L-selectin: mechanisms and physiological significance of ectodomain cleavage. J Cell Mol Med. 9, 255-266

14 Bennett, T. A., Edwards, B. S., Sklar, L. A. and Rogelj, S. (2000) Sulfhydryl regulation of $\mathrm{L}$-selectin shedding: phenylarsine oxide promotes activationindependent L-selectin shedding from leukocytes. J.Immunol. 164, 4120-4129

15 Merlos-Suarez, A., Ruiz-Paz, S., Baselga, J. and Arribas, J. (2001) Metalloprotease-dependent Protransforming Growth Factor-alpha Ectodomain Shedding in the Absence of Tumor Necrosis Factor-alpha - converting Enzyme. J.Biol.Chem. 276, 48510-48517

16 Jiang, X. M., Fitzgerald, M., Grant, C. M. and Hogg, P. J. (1999) Redox control of exofacial protein thiols/disulfides by protein disulfide isomerase. The Journal of biological chemistry. 274, 2416-2423 
17 Jordan, P. A. and Gibbins, J. M. (2006) Extracellular disulfide exchange and the regulation of cellular function. Antioxidants \& redox signaling. 8, 312-324

18 Swiatkowska, M., Szymanski, J., Padula, G. and Cierniewski, C. S. (2008) Interaction and functional association of protein disulfide isomerase with alphaVbeta3 integrin on endothelial cells. Febs J. 275, 1813-1823

19 Hotchkiss, K. A., Matthias, L. J. and Hogg, P. J. (1998) Exposure of the cryptic Arg-Gly-Asp sequence in thrombospondin-1 by protein disulfide isomerase. Biochimica et biophysica acta. 1388, 478-488

20 Jordan, P. A., Stevens, J. M., Hubbard, G. P., Barrett, N. E., Sage, T., Authi, K. S. and Gibbins, J. M. (2005) A role for the thiol isomerase protein ERP5 in platelet function. Blood. 105, 1500-1507

21 Matthias, L. J., Yam, P. T., Jiang, X. M., Vandegraaff, N., Li, P., Poumbourios, P., Donoghue, N. and Hogg, P. J. (2002) Disulfide exchange in domain 2 of CD4 is required for entry of HIV-1. Nature immunology. 3, 727-732

22 Soderberg, A., Sahaf, B. and Rosen, A. (2000) Thioredoxin reductase, a redoxactive selenoprotein, is secreted by normal and neoplastic cells: presence in human plasma. Cancer research. 60, 2281-2289

23 O'Neill, S., Robinson, A., Deering, A., Ryan, M., Fitzgerald, D. J. and Moran, N. (2000) The platelet integrin alpha IIbbeta 3 has an endogenous thiol isomerase activity. The Journal of biological chemistry. 275, 36984-36990

24 Wang, Y., Herrera, A. H., Li, Y., Belani, K. K. and Walcheck, B. (2009) Regulation of mature ADAM17 by redox agents for L-selectin shedding. J Immunol. 182, 2449-2457

25 Lee, M. H., Knauper, V., Becherer, J. D. and Murphy, G. (2001) Full-length and N-TIMP-3 display equal inhibitory activities toward TNF- alpha convertase. Biochem Biophys Res Commun. 280, 945-950

26 Kelso, G. F., Porteous, C. M., Coulter, C. V., Hughes, G., Porteous, W. K., Ledgerwood, E. C., Smith, R. A. and Murphy, M. P. (2001) Selective targeting of a redox-active ubiquinone to mitochondria within cells: antioxidant and antiapoptotic properties. J Biol Chem. 276, 4588-4596

27 D'Ortho, M.-P., Will, H., Atkinson, S., Butler, G. S., Messent, A., Gavrilovic, J., Smith, B., Timpl, R., Zardi, L. and Murphy, G. (1997) Membrane-type matrix metalloproteinases 1 and 2 exhibit broad-spectrum proteolytic capacities comparable to many matrix metalloproteinases. Eur.J.Biochem. 250, 751-757

28 Milla, M. E., Leesnitzer, M. A., Moss, M. L., Clay, W. C., Carter, H. L., Miller, A. B., Su, J. L., Lambert, M. H., Willard, D. H., Sheeley, D. M., Kost, T. A., Burkhart, W., Moyer, M., Blackburn, R. K., Pahel, G. L., Mitchell, J. L., Hoffman, C. R. and Becherer, J. D. (1999) Specific sequence elements are required for the expression of functional tumor necrosis factor-alpha-converting enzyme (TACE). J.Biol.Chem. 274, 30563-30570

29 Tokumaru, S., Higashiyama, S., Endo, T., Nakagawa, T., Miyagawa, J., Yamamori, K., Hanakawa, Y., Ohmoto, H., Yoshino, K., Shirakata, Y., Matsuzawa, Y., Hashimoto, K. and Taniguchi, N. (2000) Ectodomain shedding of epidermal growth factor receptor ligands is required for keratinocyte migration in cutaneous wound healing. J.Cell Biol. 151, 209-220

30 Robinson, A., O'Neill, S., Kiernan, A., O'Donoghue, N. and Moran, N. (2006) Bacitracin reveals a role for multiple thiol isomerases in platelet function. British journal of haematology. 132, 339-348 
31 Lundstrom, J. and Holmgren, A. (1990) Protein disulfide-isomerase is a substrate for thioredoxin reductase and has thioredoxin-like activity. The Journal of biological chemistry. 265, 9114-9120

32 Kaiser, B. K., Yim, D., Chow, I. T., Gonzalez, S., Dai, Z., Mann, H. H., Strong, R. K., Groh, V. and Spies, T. (2007) Disulphide-isomerase-enabled shedding of tumour-associated NKG2D ligands. Nature. 447, 482-486

33 Schofield, D. J., Pope, A. R., Clementel, V., Buckell, J., Chapple, S., Clarke, K. F., Conquer, J. S., Crofts, A. M., Crowther, S. R., Dyson, M. R., Flack, G., Griffin, G. J., Hooks, Y., Howat, W. J., Kolb-Kokocinski, A., Kunze, S., Martin, C. D., Maslen, G. L., Mitchell, J. N., O'Sullivan, M., Perera, R. L., Roake, W., Shadbolt, S. P., Vincent, K. J., Warford, A., Wilson, W. E., Xie, J., Young, J. L. and McCafferty, J. (2007) Application of phage display to high throughput antibody generation and characterization. Genome biology. 8, R254

34 Martin, C. D., Rojas, G., Mitchell, J. N., Vincent, K. J., Wu, J., McCafferty, J. and Schofield, D. J. (2006) A simple vector system to improve performance and utilisation of recombinant antibodies. BMC biotechnology. 6, 46

35 Studier, F. W. (2005) Protein production by auto-induction in high density shaking cultures. Protein expression and purification. 41, 207-234

36 Horiuchi, K., Le Gall, S., Schulte, M., Yamaguchi, T., Reiss, K., Murphy, G., Toyama, Y., Hartmann, D., Saftig, P. and Blobel, C. P. (2007) Substrate selectivity of epidermal growth factor-receptor ligand sheddases and their regulation by phorbol esters and calcium influx. Mol Biol Cell. 18, 176-188

37 Traore, K., Sharma, R., Thimmulappa, R. K., Watson, W. H., Biswal, S. and Trush, M. A. (2008) Redox-regulation of Erk1/2-directed phosphatase by reactive oxygen species: role in signaling TPA-induced growth arrest in ML-1 cells. Journal of cellular physiology. 216, 276-285

38 Kim, J., Lin, J., Adam, R. M., Lamb, C., Shively, S. B. and Freeman, M. R. (2005) An oxidative stress mechanism mediates chelerythrine-induced heparinbinding EGF-like growth factor ectodomain shedding. J Cell Biochem. 94, 39-49

39 Janes, P. W., Saha, N., Barton, W. A., Kolev, M. V., Wimmer-Kleikamp, S. H., Nievergall, E., Blobel, C. P., Himanen, J. P., Lackmann, M. and Nikolov, D. B. (2005) Adam meets Eph: an ADAM substrate recognition module acts as a molecular switch for ephrin cleavage in trans. Cell. 123, 291-304

$40 \mathrm{Li}, \mathrm{X}$. and Fan, H. (2004) Loss of ectodomain shedding due to mutations in the metalloprotease and cysteine-rich/disintegrin domains of the tumor necrosis factoralpha converting enzyme (TACE). J Biol Chem. 279, 27365-27375

41 Takeda, S. (2008) Three-dimensional domain architecture of the ADAM family proteinases. Semin Cell Dev Biol

42 Hogg, P. J. (2003) Disulfide bonds as switches for protein function. Trends in biochemical sciences. 28, 210-214

43 Doedens, J. R., Mahimkar, R. M. and Black, R. A. (2003) TACE/ADAM-17 enzymatic activity is increased in response to cellular stimulation. Biochem Biophys Res Commun. 308, 331-338

44 Lee, M. H., Dodds, P., Verma, V., Maskos, K., Knauper, V. and Murphy, G. (2003) Tailoring tissue inhibitor of metalloproteinases-3 to overcome the weakening effects of the cysteine-rich domains of tumour necrosis factor-alpha converting enzyme. Biochem J. 371, 369-376

45 Lee, M. H., Verma, V., Maskos, K., Becherer, J. D., Knauper, V., Dodds, P., Amour, A. and Murphy, G. (2002) The C-terminal domains of TACE weaken the inhibitory action of N-TIMP-3. FEBS Lett. 520, 102-106 
46 Guan, H. H., Goh, K. S., Davamani, F., Wu, P. L., Huang, Y. W., Jeyakanthan, J., Wu, W. G. and Chen, C. J. (2009) Structures of two elapid snake venom metalloproteases with distinct activities highlight the disulfide patterns in the D domain of ADAMalysin family proteins. J Struct Biol

47 Aballay, A., Stahl, P. D. and Mayorga, L. S. (1999) Phorbol ester promotes endocytosis by activating a factor involved in endosome fusion. J Cell Sci. 112 ( Pt 15), 2549-2557

48 Kelley, L. A. and Sternberg, M. J. (2009) Protein structure prediction on the Web: a case study using the Phyre server. Nat Protoc. 4, 363-371

\section{FIGURE LEGENDS}


Figure 1. ADAM17 mediates PMA stimulated HB-EGF shedding in HeLa cells.

a) ADAM17 siRNA, but not ADAM10 siRNA, inhibits PMA stimulated HB-EGF shedding. $72 \mathrm{~h}$ after addition of siRNA, cells were stimulated with PMA (100 $\mathrm{ng} / \mathrm{ml}$ ) for $60 \mathrm{~min}$. Cell medium was collected and analysed for alkaline phosphatase activity. b) Verification of ADAM10 and ADAM17 protein knockdown. $72 \mathrm{~h}$ after addition of ADAM10, ADAM17 or nontargeting (NT) siRNA, HeLa cells were lysed. Cell lysates were subjected to SDS-PAGE, transferred onto nitrocellulose membranes and probed with the relevant antibody. SiRNA was also tested for ADAM10 and ADAM17 cross reactivity.

Figure 2. Effect of reducing agents and ROS inhibitors on ADAM17 sheddase activity.

a) DTT reduces PMA stimulated HB-EGF shedding in HeLa cells. Cells stably transfected with an HB-EGF-AP construct were incubated with PMA (100 ng/ml), with or without DTT at various concentrations for $30 \mathrm{~min}$. Cell medium was analysed for alkaline phosphatase activity as a measure of shed HB-EGF. b) TCEP reduces PMA stimulated HB-EGF shedding in HeLa cells. Cells stably transfected with an HB-EGF-AP construct were incubated with PMA (100 ng/ml), with or without TCEP in various concentrations for $30 \mathrm{~min}$. Cell medium was analysed for alkaline phosphatase activity.

DTT $=$ Dithiothreitol, TCEP = tris (2-carboxyethyl)phosphine

c) $\mathbf{N}$-acetylcysteine inhibits PMA stimulated HB-EGF shedding in HeLa cells. HeLa cells stably transfected with an HB-EGF-AP construct were pre-incubated with different concentrations of the free radical scavenger $\mathrm{N}$-acetylcysteine (NAC) for $30 \mathrm{~min}$. Subsequently, PMA (100 ng/ml) was added to cells for $30 \mathrm{~min}$. Cell medium was collected and analysed for alkaline phosphatase activity as a measure of shed HB-EGF. d) MitoQ inhibits PMA stimulated HB-EGF shedding in HeLa cells. HeLa cells stably transfected with an HB-EGF-AP construct were preincubated with different concentrations of the mitochondrial ROS inhibitor MitoQ for $15 \mathrm{~min}$. Subsequently, PMA $(100 \mathrm{ng} / \mathrm{ml})$ was added to cells for $30 \mathrm{~min}$. Cell medium was collected and analysed for alkaline phosphatase activity as a measure of shed HB-EGF. 
Figure 3. PDI negatively regulates ADAM17 sheddase activity.

a) Inhibition of PDI increases stimulated HB-EGF shedding. Incubation of HeLa cells with the inhibitory PDI antibody RL90 and Bacitracin, a general inhibitor of thiol isomerases, increased stimulated HB-EGF shedding, but had no effect on constitutive shedding. HeLa cells were incubated with RL90 or Bacitracin for 30 and $5 \mathrm{~min}$, respectively, at $4^{\circ} \mathrm{C}$ and then treated with PMA $(100 \mathrm{ng} / \mathrm{ml})$ at $37^{\circ} \mathrm{C}$ for $30 \mathrm{~min}$. Cell medium was analysed for alkaline phosphatase activity. b) ADAM17 mediates increased PMA stimulated HB-EGF shedding by inhibition of PDI. $72 \mathrm{~h}$ after addition of siRNA, cells were pre-incubated with Bacitracin or the inhibitory PDI antibody RL90 and stimulated with PMA $100 \mathrm{ng} / \mathrm{ml}$ for $30 \mathrm{~min}$. Cell medium was analysed for alkaline phosphatase activity c) Effect of exogenous PDI on ADAM17. After $10 \mathrm{~min}$ pre-incubation with reduced PDI at various concentrations, HeLa cells were stimulated with PMA $100 \mathrm{ng} / \mathrm{ml}$ for $30 \mathrm{~min}$. Cell medium was analysed for alkaline phosphatase activity. d) Alkylated PDI has no effect on ADAM17 activity. After incubation with exogenous reduced or reduced and alkylated PDI (500 nM) for 10 min, cells were stimulated with PMA (100 ng/ml) for $30 \mathrm{~min}$. Cell medium was analysed for alkaline phosphatase activity. e) PDI knockdown increases PMA stimulated ADAM17 activity. $72 \mathrm{~h}$ after addition of siRNA, cells were stimulated with PMA $100 \mathrm{ng} / \mathrm{ml}$ for $30 \mathrm{~min}$. Cell medium was analysed for alkaline phosphatase activity. f) Verification of PDI siRNA. Measurement of PDI protein expression after addition of PDI siRNA to HeLa cells relative to a control, nontargeting (NT) siRNA. $72 \mathrm{~h}$ after addition of siRNA, cells were lysed, cell lysates were subjected to SDS-PAGE, transferred to membrane and probed with a PDI antibody.

Figure 4. ScFv antibodies detect PDI modulation of ADAM17.

a) ScFv antibodies bind recombinant human ADAM17 ectodomain. ScFv antibodies selected against the ADAM17 ectodomain were isolated by phage display technology. Titration ELISAs of affinity purified recombinant scFvs indicated these antibodies bound ADAM17 with low nanomolar affinities. b) ScFvs bind to specific regions of ADAM17 and do not bind ADAM10. The ADAM17 
ectodomain (Arg215-Arg651), ADAM17 catalytic (metalloproteinase) domain (Arg215-Val477) and ADAM10 ectodomain (Thr214-Glu672) were ELISA probed with each scFv to obtain basic epitope and specificity information. Whilst scFv A9 bound directly to the ADAM17 catalytic domain, scFvs A7 and D3 did not. None of the scFvs cross-react with ADAM10. c) ScFvs A7 and A9 have disulphide dependent epitopes. Pre-treatment of ADAM17 ectodomain with $100 \mu \mathrm{M}$ DTT abolished the immunoreactivity of scFvs $A 7$ and $A 9$, whilst the binding of ScFv D3 and a polyclonal $\lg Y$ remained unaltered. This suggested $A 7$ and $A 9$ harboured disulphide dependent epitopes. d) PDI modifies ADAM17 non-catalytic regions. Biotinylated recombinant human ADAM17 ectodomain $(10 \mu \mathrm{M})$ was incubated with either $100 \mu \mathrm{M}$ DTT, $30 \mu \mathrm{M}$ reduced PDI or $30 \mu \mathrm{M}$ alkylated PDI. ADAM17 was subsequently immobilised on a streptavidin coated ELISA plate and excess PDI was removed by multiple PBS-Tween $(0.1 \%, v / v)$ washes. The topological status of the ADAM17 catalytic domain was then probed using scFvs A9 (catalytic epitope), A7 (non-catalytic epitope), D3 (non-catalytic epitope) and an anti-ADAM17 polyclonal IgY. Whilst the ADAM17 catalytic domain is a disulphide dependant structure (all A9 scFv binding lost after direct reduction), PDI treatment of the ectodomain did not alter the epitope of ScFv A9. In contrast, the ADAM17 noncatalytic epitopes of A7 and D3 were abolished by treatment with reduced PDI. Inactive alkylated PDI did not disrupt any antibody binding. e) PDI modification of ADAM17 ectodomain blocks N-TIMP-3 binding. ADAM17 ectodomain was treated as described in $\mathrm{d}$ ) and probed with the N-terminal domain of TIMP-3, NTIMP-3. Despite the apparent structural integrity of the catalytic domain following PDI treatment (A9 binding unaltered), PDI modification of ADAM17 dramatically obstructed N-TIMP-3 binding.

Fig 5. The Effect of PDI on the activity of the ADAM17 ectodomain.

a) Peptide substrate assay. $0.8 \mathrm{mM}$ recombinant ADAM17 ectodomain was incubated in $50 \mathrm{mM}$ Tris- $\mathrm{HCl}, 10 \mathrm{mM} \mathrm{CaCl}_{2}, \mathrm{pH} 7.4$ either with or without a threefold molar excess of untreated PDI at RT for the times stated. Aliquots were removed and assayed for ADAM17 activity against the fluorogenic substrate methoxycoumarinylacetyl-Lys-Pro-Leu-Gly-Leu-dinitrophenyl diaminopropionyl-Ala- 
Arg- $\mathrm{NH}_{2}$ (2 mM in FAB buffer: $50 \mathrm{mM}$ Tris- $\mathrm{HCl}, 10 \mathrm{mM} \mathrm{CaCl}, 0.05 \%(\mathrm{v} / \mathrm{v}) \mathrm{Brij} 35$, $1 \%$ (v/v) DMSO, pH 7.4). Reactions were run for $1000 \mathrm{sec}$ in an LS50B spectrophotometer, in a total volume of $2 \mathrm{ml}$ with excitation at $320 \mathrm{~nm}$ and emission at $405 \mathrm{~nm}$. Activities are expressed as a percentage of the untreated control. b) Protein substrate assay. $100 \mathrm{nM}$ recombinant ADAM17 was treated with increasing concentrations of PDI $(0-800 \mathrm{nM})$, or alkylated PDI $(800 \mathrm{nM})$ in FAB buffer for $2 \mathrm{~h}$ at $37^{\circ} \mathrm{C}$. GST-proTNFa $(5 \mu \mathrm{M})$ was added to samples and incubated for $2 \mathrm{~h}$ at $37^{\circ} \mathrm{C}$. Incubations were resolved by reducing $12 \%$ SDS-PAGE and stained with Coomassie Brilliant Blue.

Figure 6. Analysis of ADAM17 and PDI at the HeLa cell surface.

a) The effect of PMA stimulation on ADAM17 and PDI cell surface expression. After exposure of HeLa cells to PMA (100 $\mathrm{ng} / \mathrm{ml})$ for $30 \mathrm{~min}$, surface free thiols and amine groups were biotinylated for $45 \mathrm{~min}$ at $4^{\circ} \mathrm{C}$. Then streptavidin immunoprecipitation was performed, samples were subjected to SDS-PAGE and Western blot and probed with specific antibodies against ADAM17 and PDI. A $\beta$ actin control was used to assess biotinylation of intracellular proteins, which could not be detected. b) Graphs reflecting the average values of three individual experiments as performed in figure 8a, quantified by densitometry. c) The effect of $\mathbf{N}$-acetylcysteine on total and free thiol levels of cell surface PDI. Cells were exposed to $1 \mathrm{mM} \mathrm{NAC}$ for $15 \mathrm{~min}$, then to PMA (100 ng/ml) with NAC for $30 \mathrm{~min}$ at $37^{\circ} \mathrm{C}$. Subsequently, amine groups were biotinylated for $45 \mathrm{~min}$ at $4^{\circ} \mathrm{C}$. Streptavidin immunoprecipitation was performed, samples were subjected to SDS-PAGE and Western blot and probed with a PDI antibody. d) PDI transiently interacts with ADAM17 at the HeLa cell surface. After exposure to PMA (100 ng/ml) for $30 \mathrm{~min}$, HeLa cells were surface biotinylated (amine groups). For stabilisation of disulphide bonds, cells were then incubated in 10\% (v/v) TCA in PBS for $30 \mathrm{~min}$, before $\mathrm{pH}$ was adjusted to 7.0 with Tris-OH (pH 9.5). Cells were lysed and ADAM17 immunoprecipitation was performed. After releasing the immunocomplex from the beads, a secondary immunoprecipitation was performed for streptavidin. Samples were subjected to SDS-PAGE and Western blot, after which membranes were probed with specific antibodies. 
Figure 7. Model of PDI isomerisation of ADAM17 ectodomain

ADAM17 homology models permit multiple ectodomain conformations [48]. In vitro data suggest PDI-mediated thiol isomerisation of the ADAM17 non-catalytic domains (blue) disrupt accessibility to its catalytic domain (red) ("Closed" ADAM17). PDI antagonists consent reversal of this process - with subsequent re-accessibility of the catalytic zinc (white) ("Open" ADAM17). The mechanism of this reversal requires further investigation.

Supplementary figures

Figure S1. PMA stimulation causes HB-EGF shedding in HeLa cells, which can be blocked by inhibitors of metalloproteases.

a) Time-course of PMA-induced HB-EGF shedding in HeLa cells. Cells stably transfected with an HB-EGF-AP construct were stimulated with PMA $(100 \mathrm{ng} / \mathrm{ml})$ for up to $4 \mathrm{~h}$, subsequently the cell medium was analysed for alkaline phosphatase activity as a measure of shed HB-EGF. b) TIMP-3 or low molecular weight hydroxamate inhibitors of metalloproteases (BB94 and CT1746) inhibit PMA stimulated HB-EGF shedding. HeLa cells stably transfected with an HB-EGF-AP construct were pre-incubated for $10 \mathrm{~min}$ with TIMP-3 (500 nM), hydroxamate inhibitors $(5 \mu \mathrm{M})$ or DMSO (vehicle), followed by 30 min PMA stimulation (100 $\mathrm{ng} / \mathrm{ml})$. Cell medium was analysed for alkaline phosphatase activity.

Figure S2. PMA stimulated HB-EGF shedding in MCF7 cells is mediated by ADAM17.

a) ADAM17 siRNA inhibits PMA stimulated HB-EGF shedding in MCF7 cells. $72 \mathrm{~h}$ after addition of ADAM17 siRNA, cells were stimulated with PMA (50 ng/ml) for $30 \mathrm{~min}$. Cell medium was collected and analysed for alkaline phosphatase activity b) Verification of ADAM17 protein knockdown. $72 \mathrm{~h}$ after addition of ADAM17 or nontargeting (NT) siRNA, MCF7 cells were lysed. Cell lysates were 
subjected to SDS-PAGE, transferred onto nitrocellulose membranes and probed with the relevant antibody.

Figure S3. PDI negatively regulates ADAM17 sheddase activity in MCF7 cells.

a) Inhibition of PDI increases stimulated HB-EGF shedding. Incubation of MCF7 cells with the inhibitory PDI antibody RL90 or Bacitracin, a general inhibitor of thiol isomerases, increased stimulated HB-EGF shedding, but had no effect on constitutive shedding. MCF7 cells were incubated with RL90 or Bacitracin for 30 and $5 \mathrm{~min}$, respectively, at $4^{\circ} \mathrm{C}$ and then treated with $\mathrm{PMA}(50 \mathrm{ng} / \mathrm{ml})$ at $37^{\circ} \mathrm{C}$ for 30 min. Cell medium was analysed for alkaline phosphatase activity. b) Effect of exogenous PDI on ADAM17. After 10 min pre-incubation with reduced PDI at various concentrations, MCF7 cells were stimulated with PMA (50 ng/ml) for $30 \mathrm{~min}$. Cell medium was analysed for alkaline phosphatase activity.

Figure S4. Effect of PMA on total cellular HB-EGF-AP and cell surface HBEGF in HeLa cells.

After exposure of HeLa cells to PMA (100 $\mathrm{ng} / \mathrm{ml})$ for $30 \mathrm{~min}$, cells were either lysed, or first surface biotinylated (amine groups) for $45 \mathrm{~min}$ at $4^{\circ} \mathrm{C}$ and then lysed. For the biotinylated samples, streptavidin immunoprecipitation was performed. Samples were then subjected to SDS-PAGE and Western blot and probed with an HB-EGF antibody.

Figure S5. ADAM17 remains fully oxidised following treatment with reduced PDI.

Recombinant human ADAM17 ectodomain was incubated with either DTT (lane 1) or alone (lane 2). DTT reduced PDI (lane 3,5) and alkylated PDI (lane 4,6) were incubated alone (lanes 3,5 ) or with ADAM17 (lanes 5,6) at $37^{\circ} \mathrm{C}$ for $2 \mathrm{~h}$. The subsequent thiol status of each mixture was investigated by MPB labelling (molar ratio ADAM17:MPB 1:10) for $2 \mathrm{~h}$ at RT. Samples were resolved by SDS-PAGE, transferred to a nitrocellulose membrane and blotted for extra avidin HRP. 


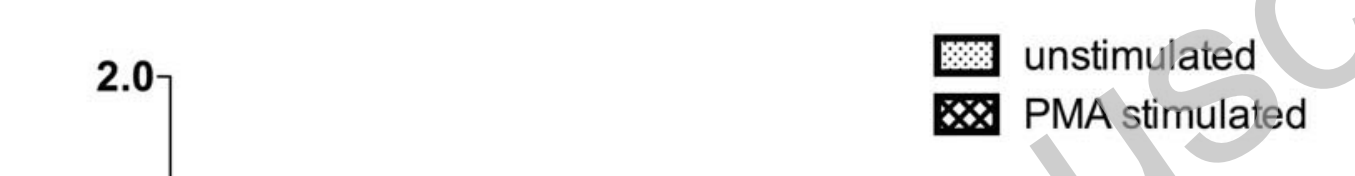




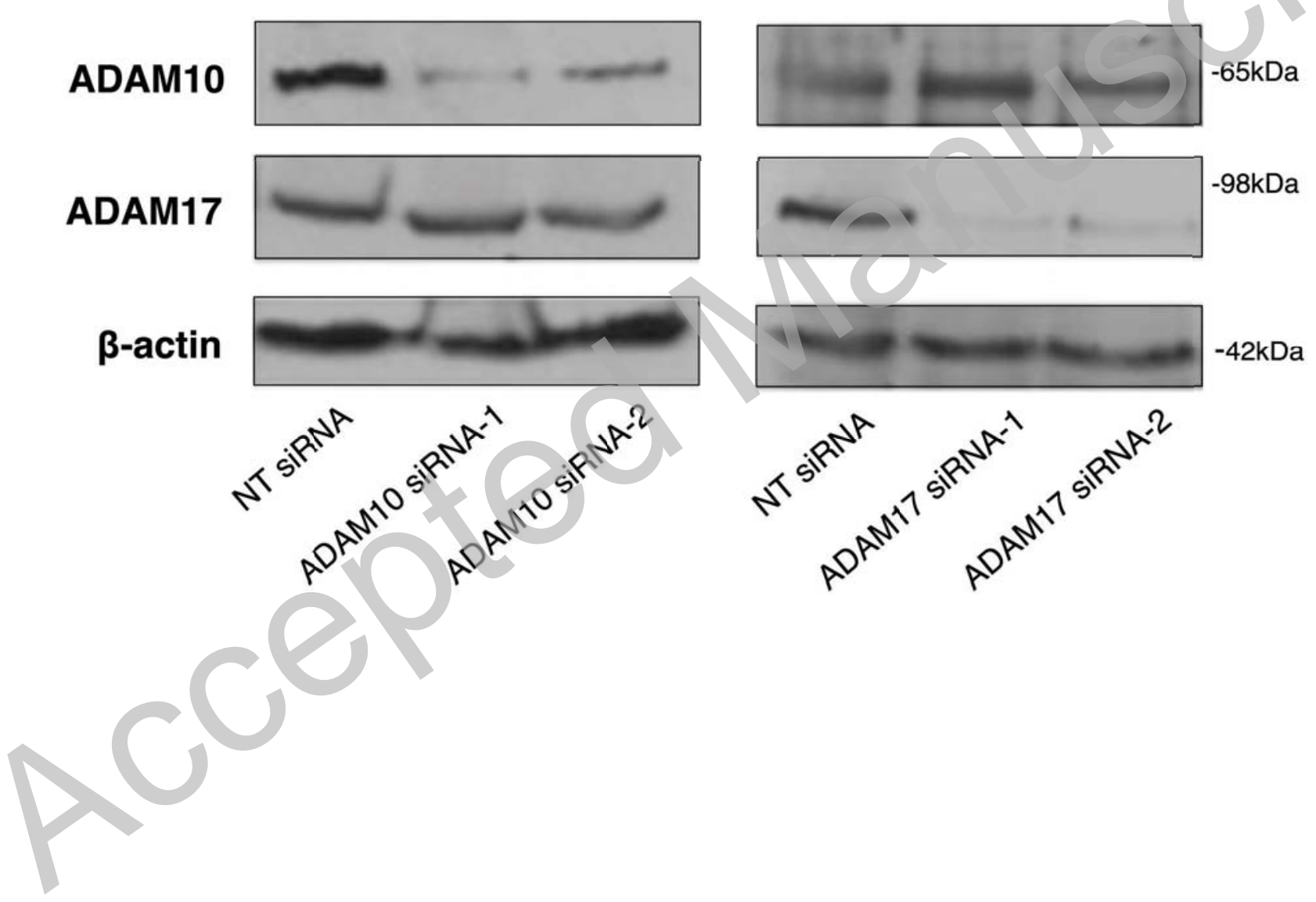




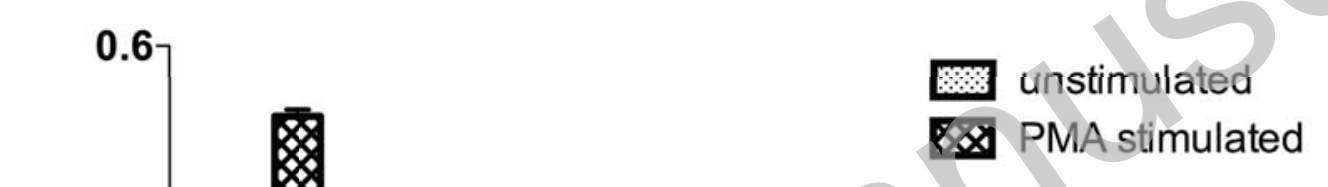



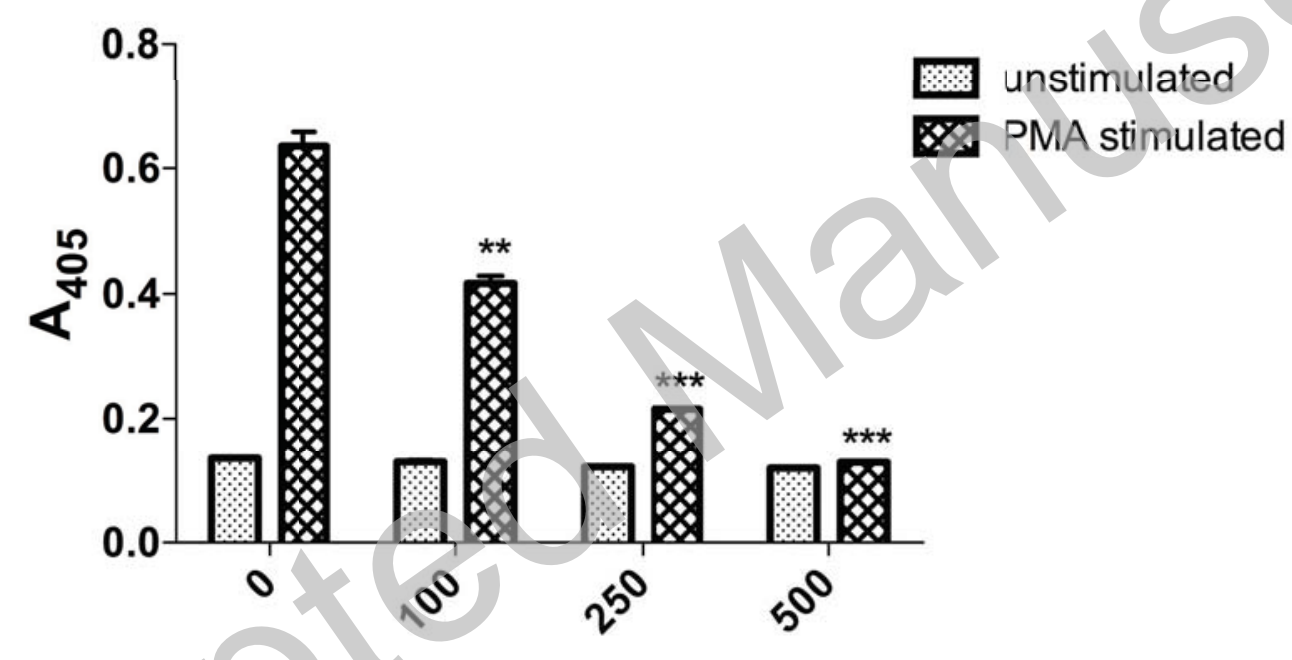

concentration TCEP $(\mu \mathrm{M})$ 


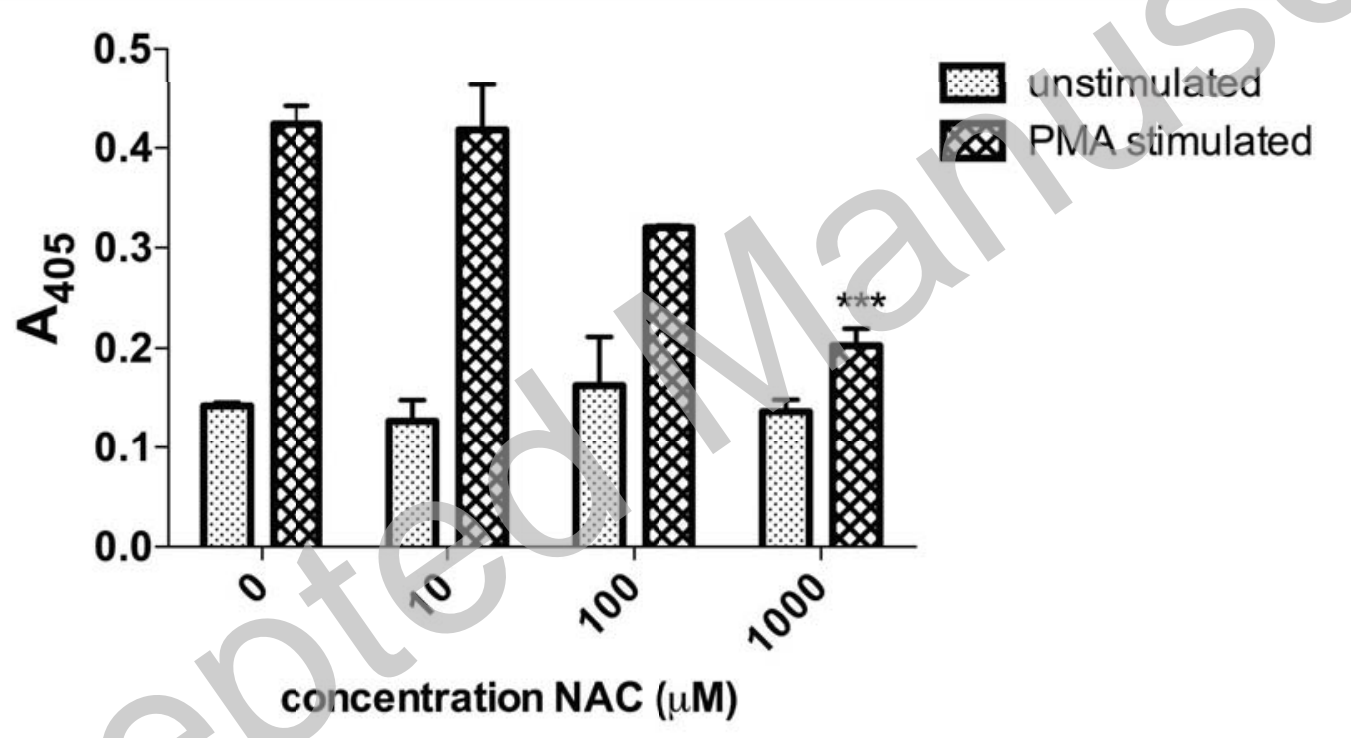



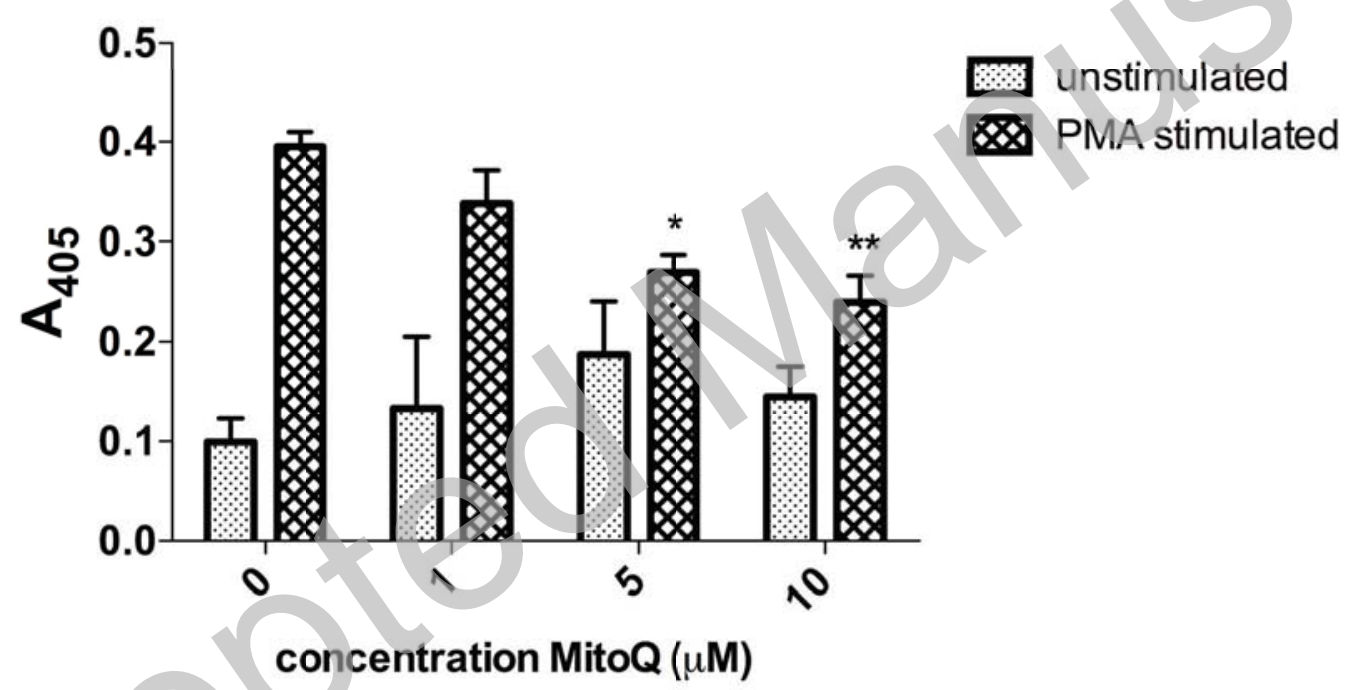


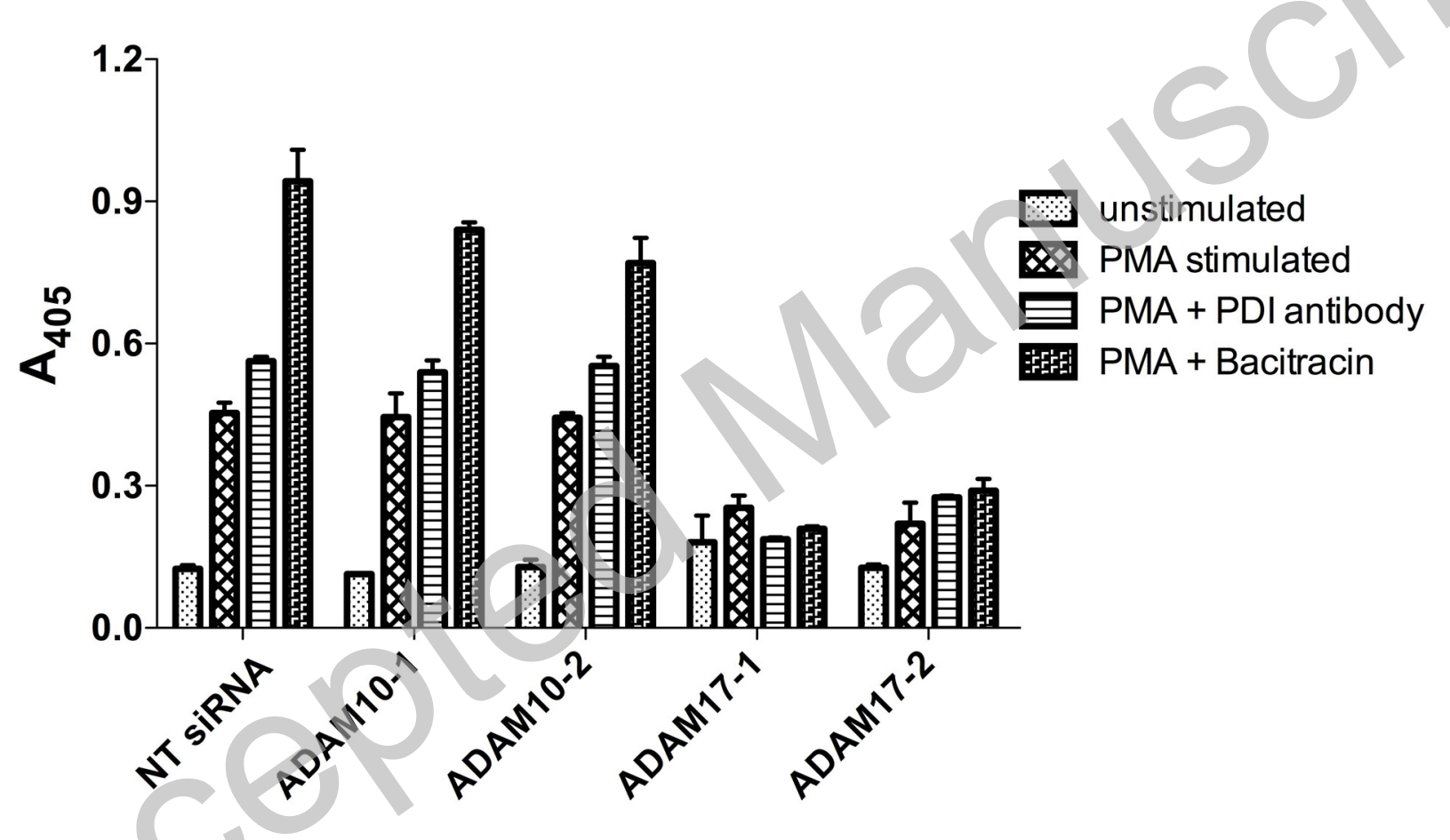




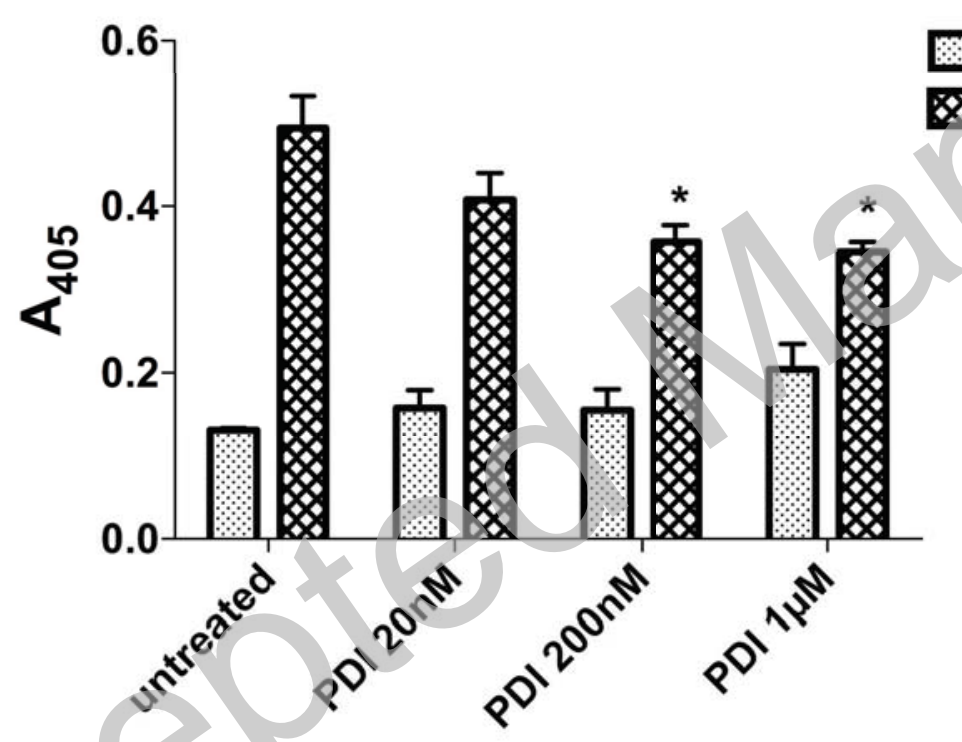



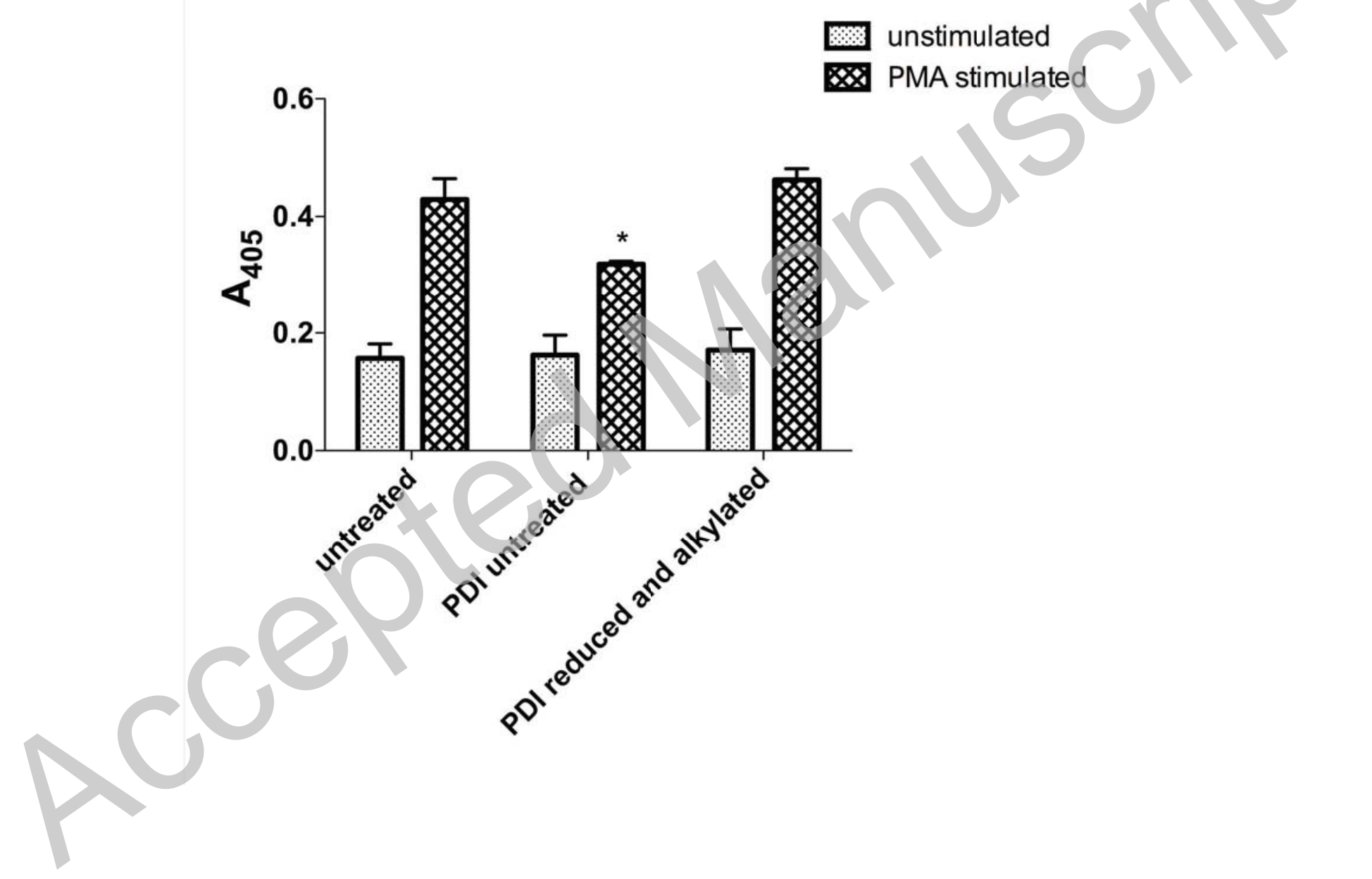


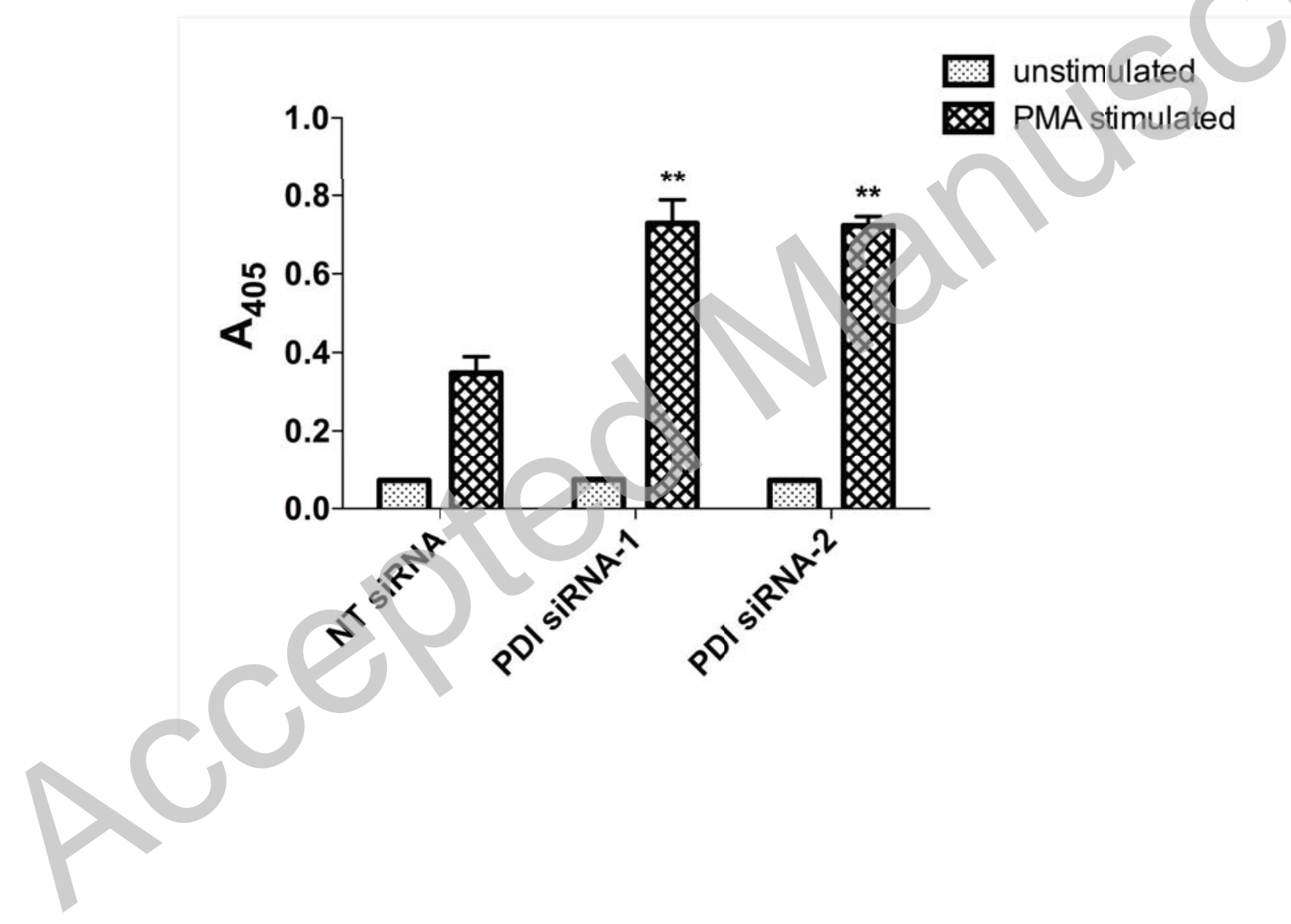




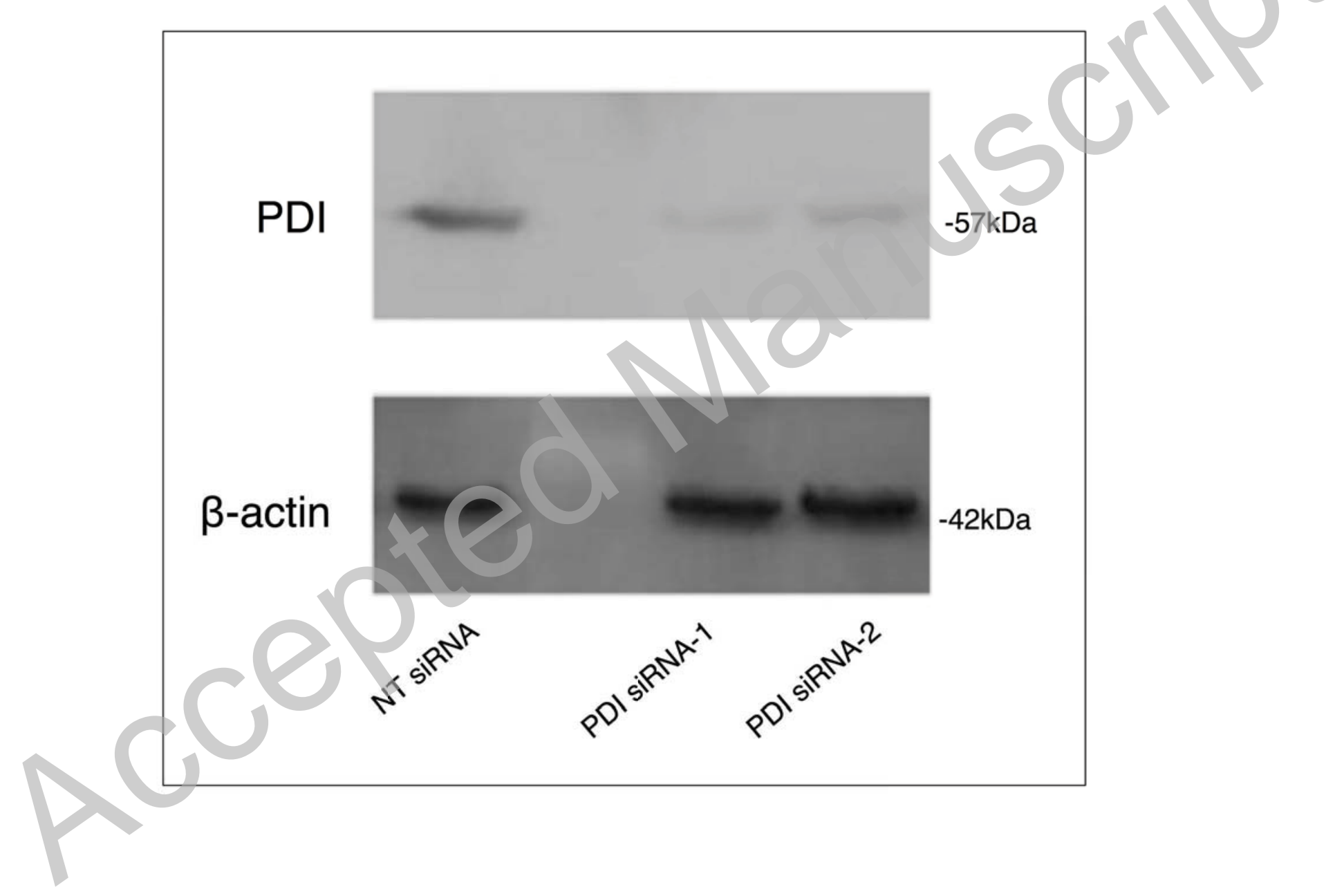


B Biochemical Journal Immediate Publication. Published on 29 Mar 2010 as manuscript BJ20100179

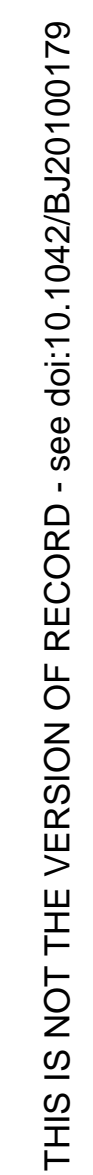

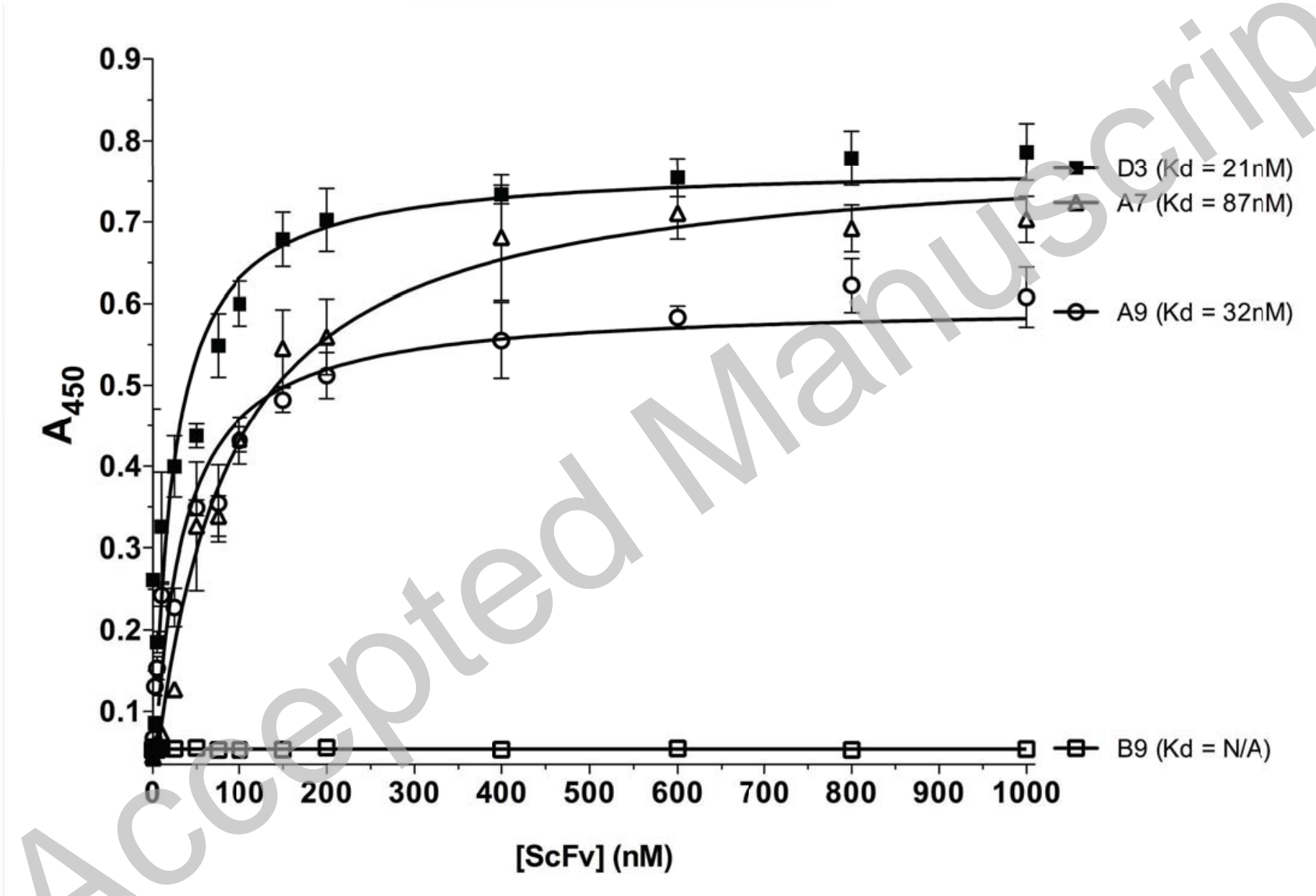

Licenced copy. Copying is not permitted, except with prior permission and as allowed by law.

(C) 2010 The Authors Journal compilation (@ 2010 Portland Press Limited 


\section{B Biochemical Journal Immediate Publication. Published on 29 Mar 2010 as manuscript BJ20100179}

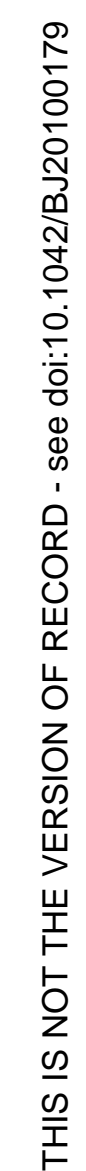
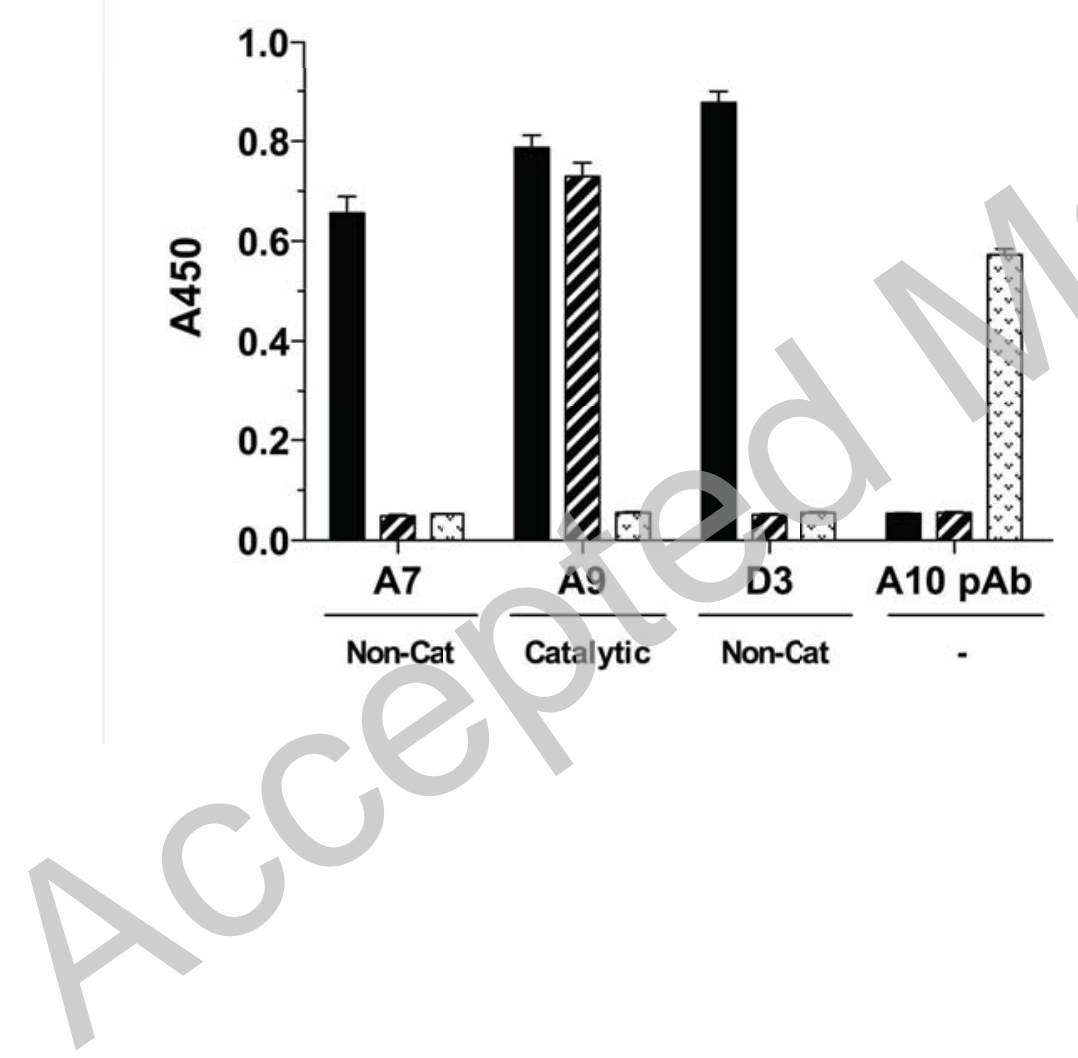

51 ADAM17 Ectodomain

VIA ADAM17 Catalytic Domain

F ADAM10 Ectodomain

Probe

Epitope Information 


\section{B Biochemical Journal Immediate Publication. Published on 29 Mar 2010 as manuscript BJ20100179}

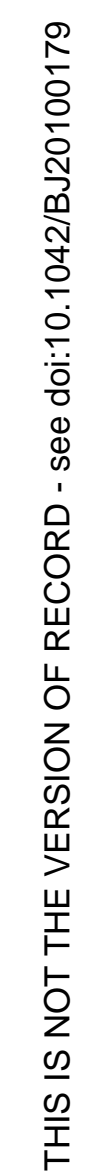

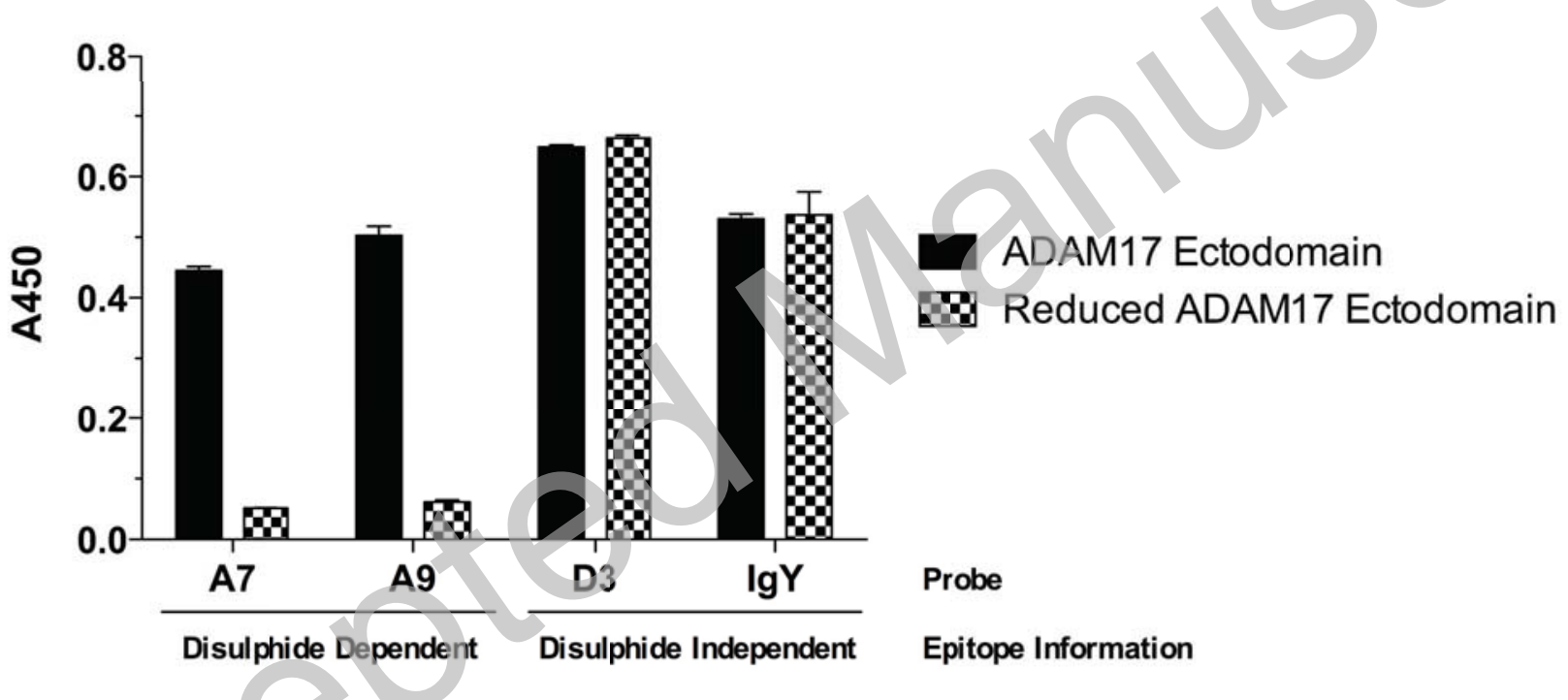




\section{R Biochemical Journal Immediate Publication. Published on 29 Mar 2010 as manuscript BJ20100179}

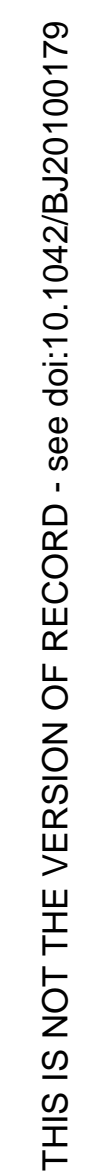

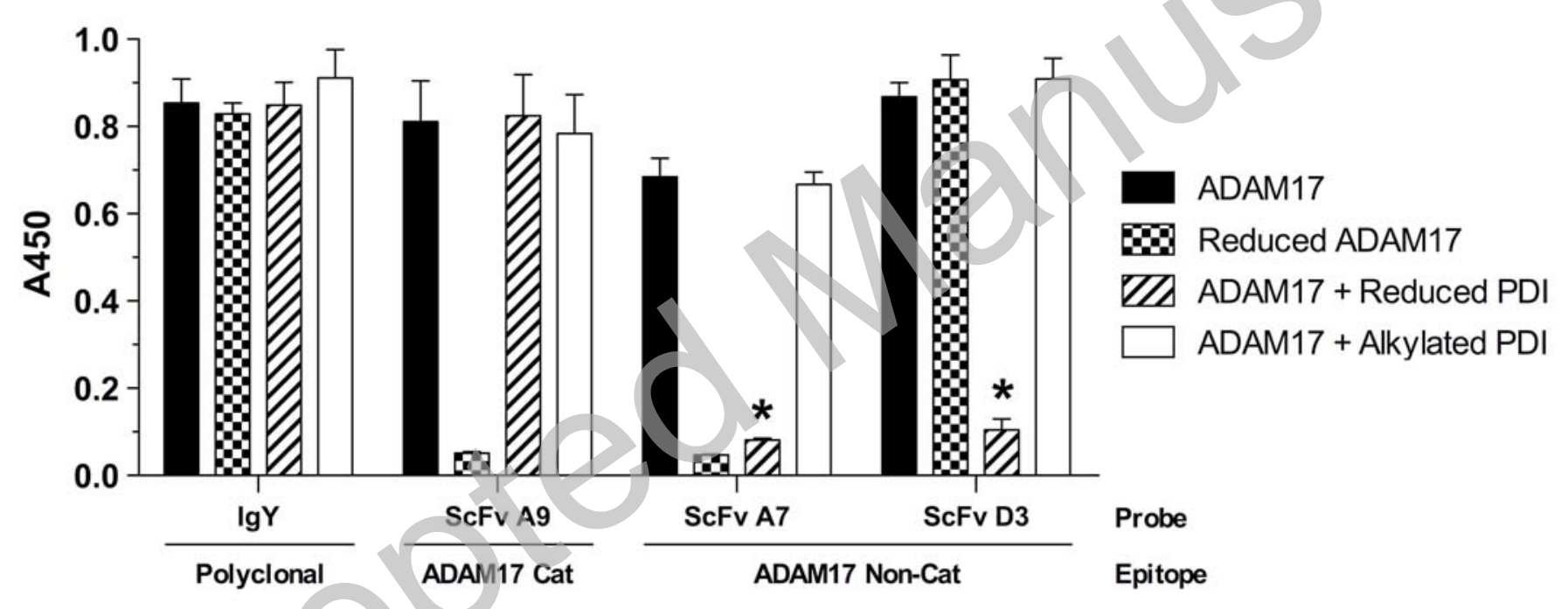




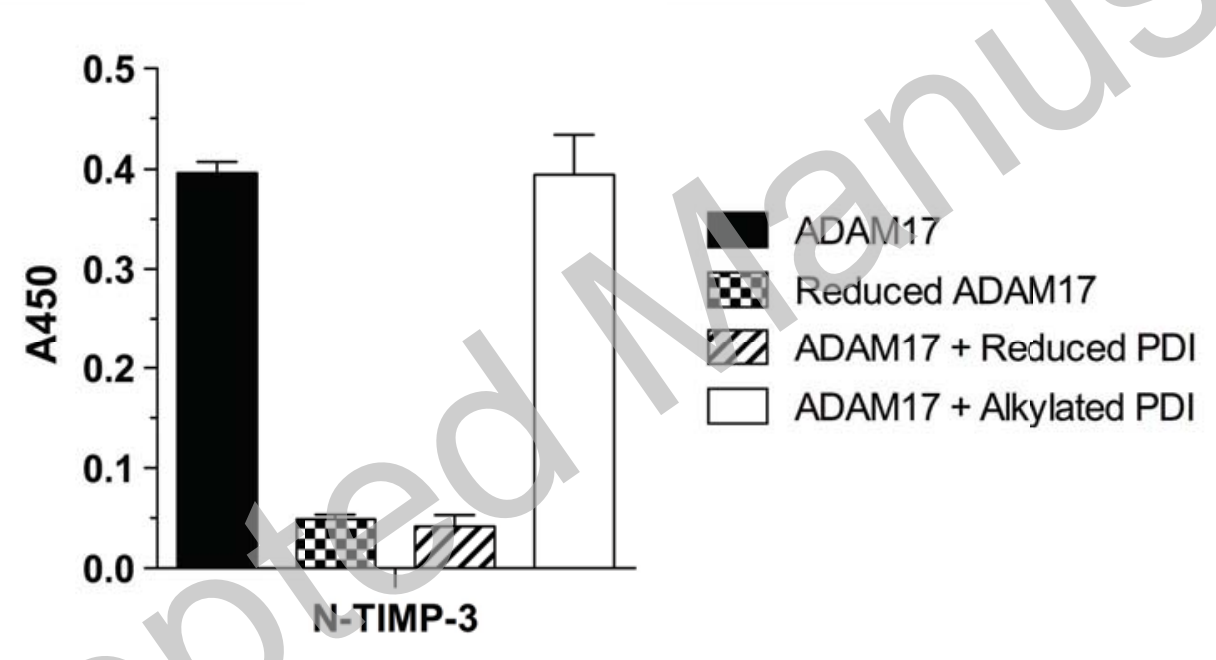




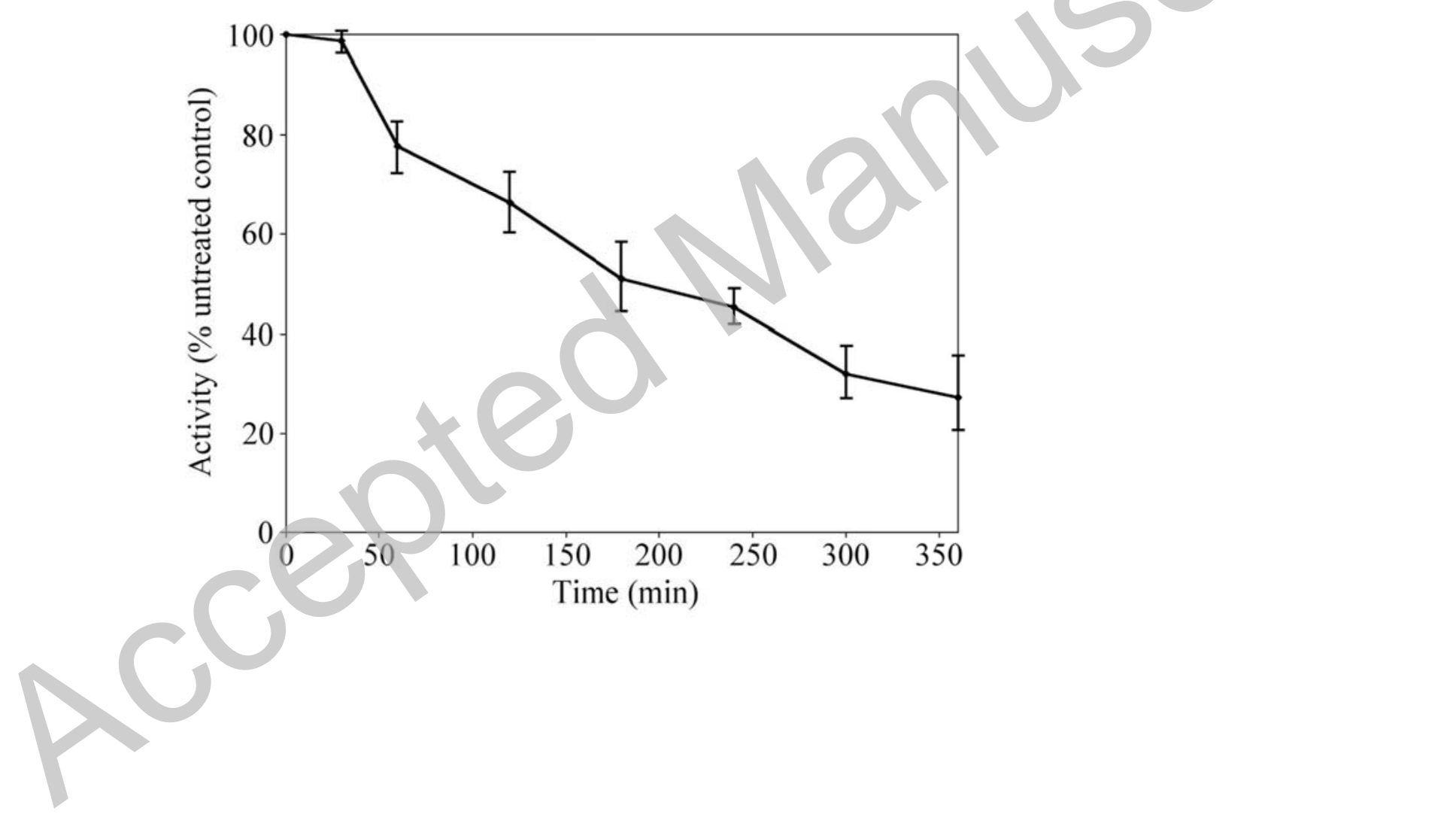




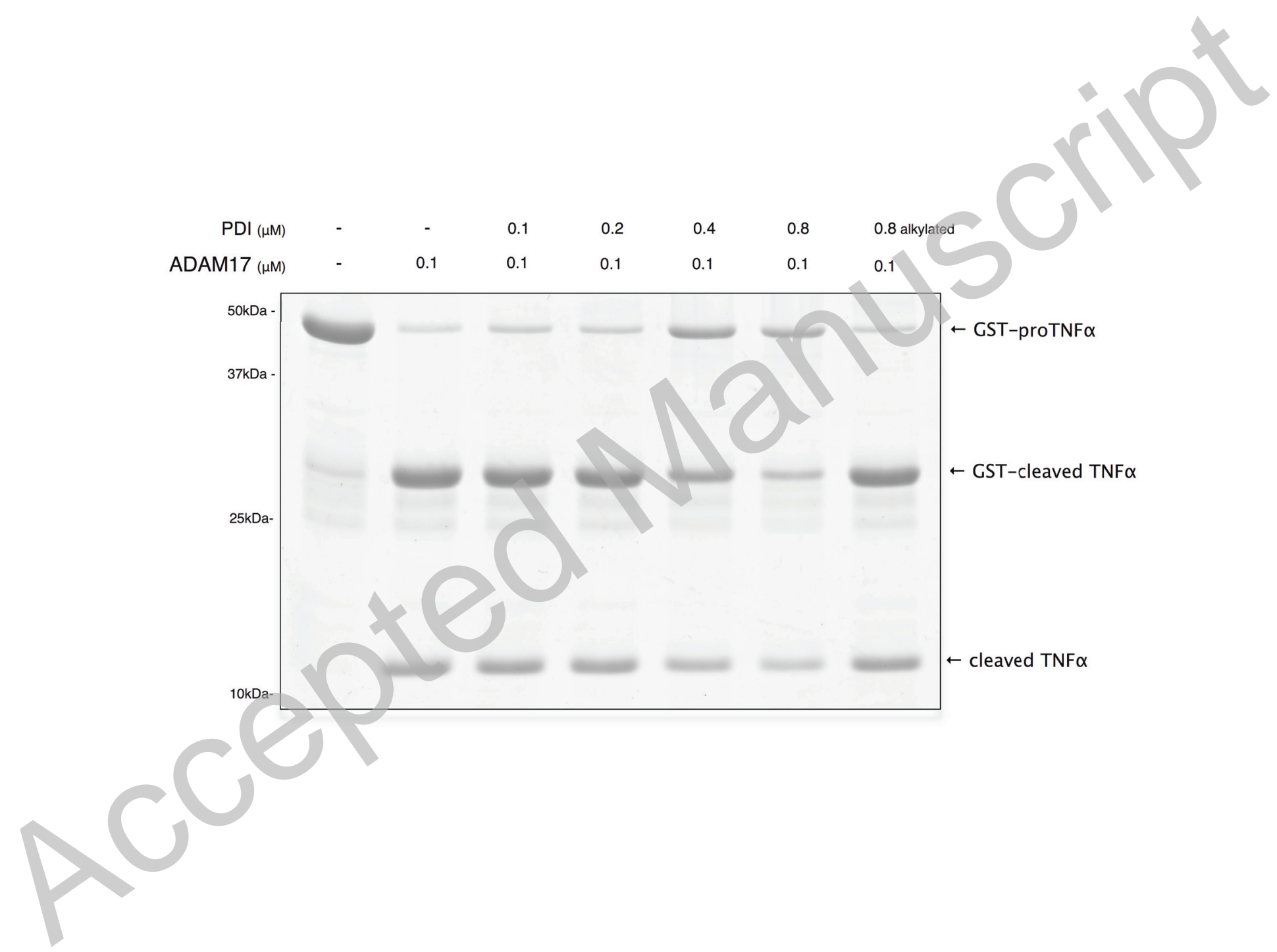


B Biochemical Journal Immediate Publication. Published on 29 Mar 2010 as manuscript BJ20100179

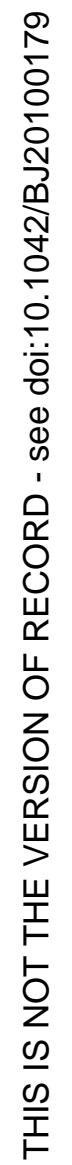
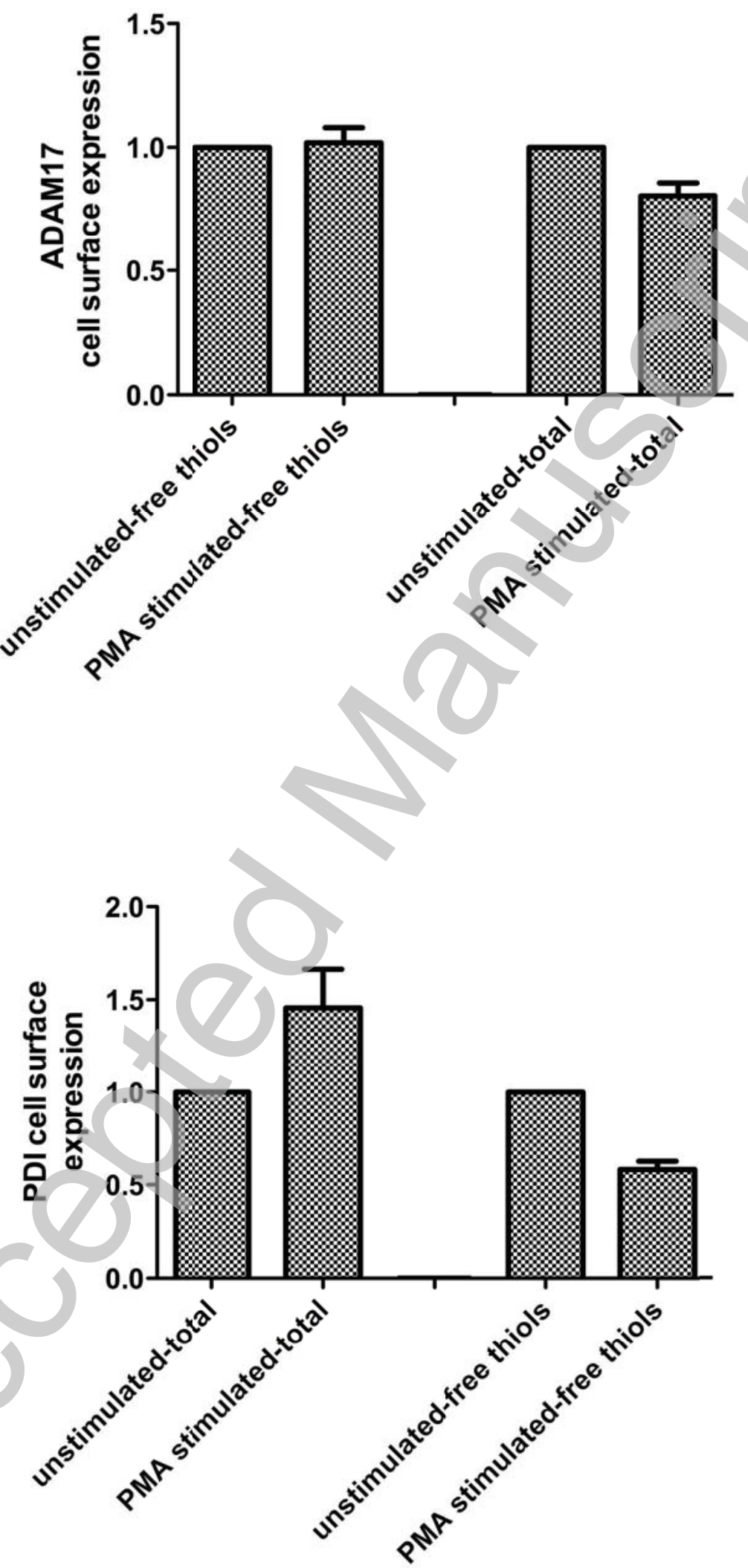

Licenced copy. Copying is not permitted, except with prior permission and as allowed by law. (C) 2010 The Authors Journal compilation (c) 2010 Portland Press Limited 


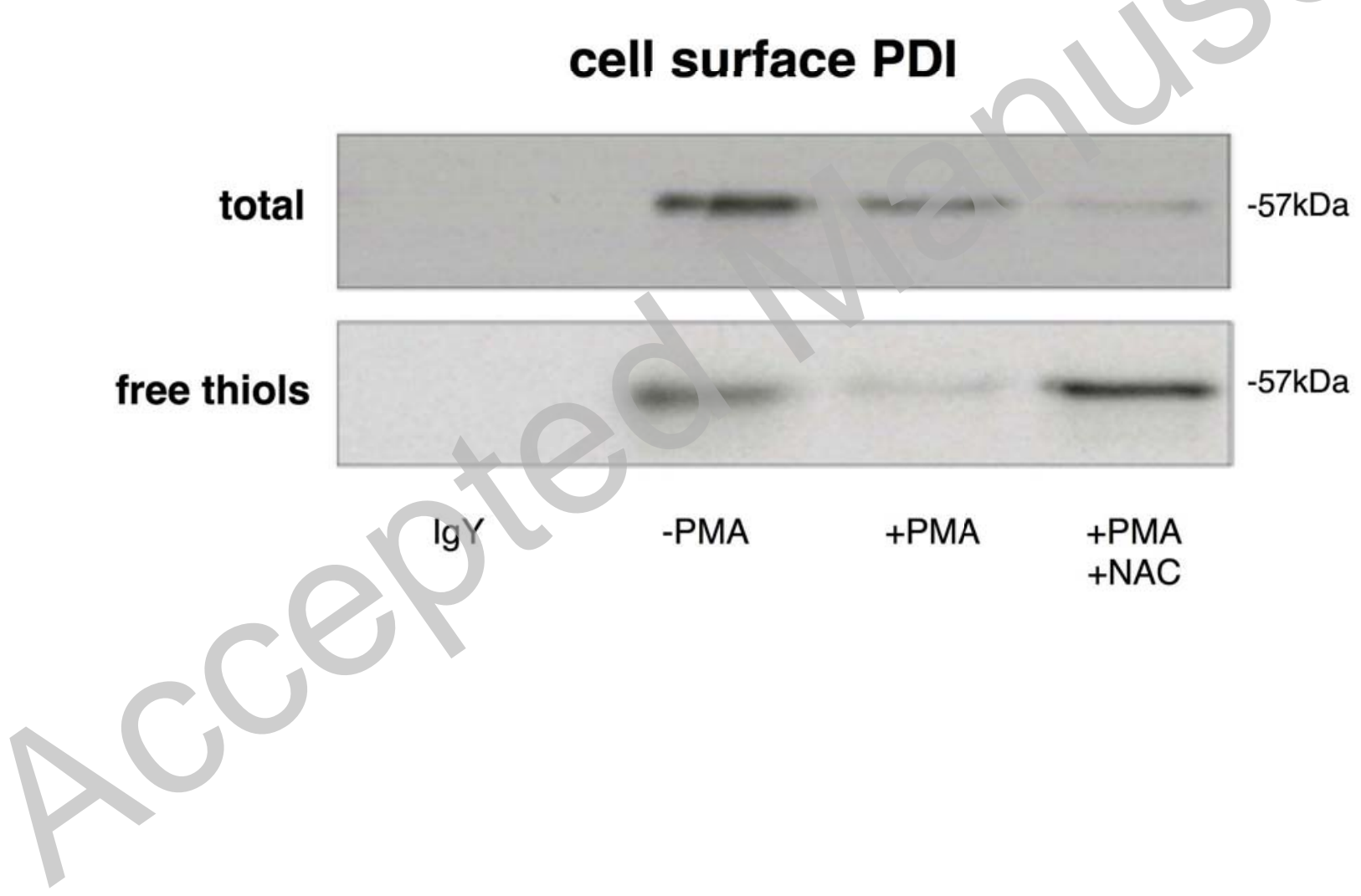




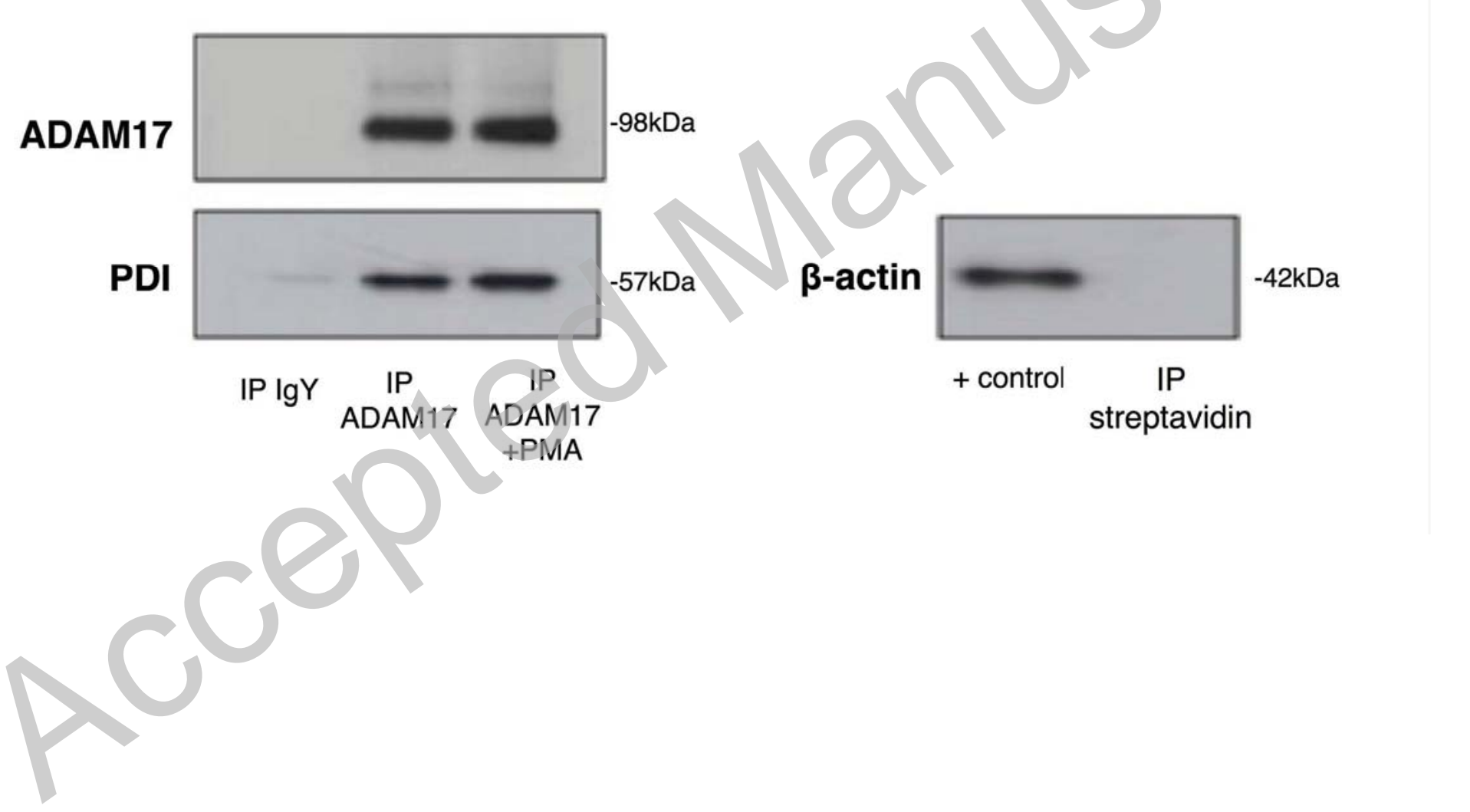




\section{B Biochemical Journal Immediate Publication. Published on 29 Mar 2010 as manuscript BJ20100179}

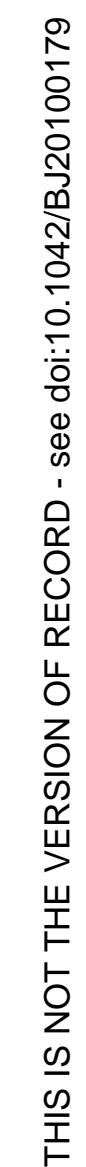

